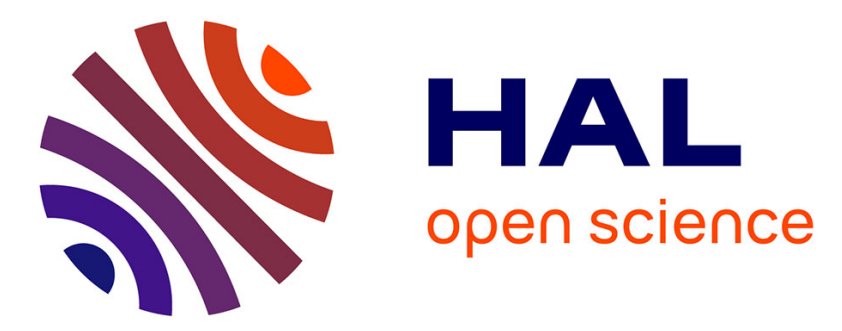

\title{
New insights into lignin electrolysis on nickel-based electrocatalysts: Electrochemical performances before and after oxygen evolution
}

K. Beliaeva, N. Grimaldos-Osorio, E. Ruiz-Lopez, L. Burel, P. Vernoux, A. Caravaca

\section{To cite this version:}

K. Beliaeva, N. Grimaldos-Osorio, E. Ruiz-Lopez, L. Burel, P. Vernoux, et al.. New insights into lignin electrolysis on nickel-based electrocatalysts: Electrochemical performances before and after oxygen evolution. International Journal of Hydrogen Energy, 2021, 46 (72), pp.35752-35764. 10.1016/j.ijhydene.2021.01.224 . hal-03404313

\section{HAL Id: hal-03404313 https://hal.science/hal-03404313}

Submitted on 9 Nov 2021

HAL is a multi-disciplinary open access archive for the deposit and dissemination of scientific research documents, whether they are published or not. The documents may come from teaching and research institutions in France or abroad, or from public or private research centers.
L'archive ouverte pluridisciplinaire HAL, est destinée au dépôt et à la diffusion de documents scientifiques de niveau recherche, publiés ou non, émanant des établissements d'enseignement et de recherche français ou étrangers, des laboratoires publics ou privés. 


\title{
New insights into lignin electrolysis on nickel-based electrocatalysts: Electrochemical performances before and after oxygen evolution
}

\author{
K. Beliaeva ${ }^{1}$, N. Grimaldos-Osorio ${ }^{1}$, E. Ruiz-López ${ }^{1,2}$, L. Burel ${ }^{1}$, P. Vernoux ${ }^{1 *}$, A. Caravaca $^{1 *}$ \\ ${ }^{1}$ Université de Lyon, Institut de Recherches sur la Catalyse et l'Environnement de Lyon, UMR 5256, CNRS, \\ Université Claude Bernard Lyon 1, 2 avenue A. Einstein, 69626 Villeurbanne, France \\ ${ }^{2}$ Department of Chemical Engineering, School of Chemical Sciences and Technologies, University of Castilla- \\ La Mancha, Avenida Camilo José Cela 12, 13071 Ciudad Real, Spain
}

Keywords: Lignin electrolysis, $\beta-\mathrm{O}-4$ linkage model, hydrogen production, Ni-based electrocatalyst

*Corresponding authors: angel.caravaca@ircelyon.univ-lyon1.fr philippe.vernoux@ircelyon.univ-lyon1.fr 


\begin{abstract}
The production of $\mathrm{H}_{2}$ via electrolysis seems to be the best alternative to traditional catalytic reforming processes. The electrolysis of lignin allows to produce pure $\mathrm{H}_{2}$ while valorizing a low-price biomass waste with (theoretically) lower energy requirements than water electrolysis. Previous studies were published in the last years dealing with the electro-oxidation of lignin on Ni-based catalysts. Ni is a robust non-expensive metal that presents a wide variety of oxidation states and phase transitions. To this date, it is still not completely clear how these states/transitions activate the lignin molecule. The aim of this study is to get more insights into the cleavage of the main chemical bonds present in the complex lignin structure over different $\mathrm{Ni}$ oxidation states. A Ni/C catalyst, prepared by the polyol method, was thoroughly characterized and tested for the electro-oxidation of both, lignin and 2-phenoxyethanol, where the latter is a model molecule representative of the quintessential $\beta-\mathrm{O}-4$ linkage in lignin.
\end{abstract}




\section{Introduction}

Hydrogen, as a potential energy carrier for stationary, and mainly for dynamic applications, is gaining exponentially growing attention in the last years. The most representative example is that some of the main automotive manufacturers are currently developing new vehicles powered with hydrogen-fuel cells [1]. The bottleneck in the hydrogen economy remains the efficient, economical and environmentally friendly production of this energy vector. In this sense, natural gas steam reforming, which accounts traditionally for over $90 \%$ of the $\mathrm{H}_{2}$ production [2], does not seem to be a suitable technology in the long-run due to the following issues: i) natural gas is a fossil fuel (not environmentally friendly) with limited stock, ii) together with $\mathrm{H}_{2}$, CO is produced in the same gas mixture, with the subsequent need of additional units for further $\mathrm{H}_{2}$ purification, iii) this process is usually performed under severe reaction conditions (temperatures over $700{ }^{\circ} \mathrm{C}$ and high pressures $[3,4]$ ), with the subsequent energy and economic penalty and iv) this technology leads to carbon-based emissions, and therefore is not compatible with a future decarbonized energy system.

To overcome the main issues of that technology, water electrolysis is presented as one of the main alternatives. This process allows for the electrochemical cleavage of the water molecule into pure $\mathrm{H}_{2}$ and $\mathrm{O}_{2}$ upon the application of electrical polarizations without emissions of pollutants or $\mathrm{CO}_{2}$. Water electrolysis takes usually place on non-noble metal electrodes, mainly nickel-based materials, although other promising materials, such as $\mathrm{Cu}$-based and Co-based, have been recently proposed as promising electrodes [5-7]. Compared to traditional steam reforming technologies, water is an environmentally friendly molecule with (relatively) unlimited stock, the hydrogen produced does not need for any further purification, and the process is performed under mild reaction conditions (generally below $90{ }^{\circ} \mathrm{C}$ ) [8]. The general idea is to couple this technology to renewable energy resources (wind, solar, tidal), in a way that the excess of energy produced by those could be stored in the form of $\mathrm{H}_{2}$. Nevertheless, at 
low temperatures, the thermodynamics for the water electrolysis process dictate that a minimum cell voltage of $1.23 \mathrm{~V}$ should be overcome before $\mathrm{H}_{2}$ actually evolves $[9,10]$. The anodic oxygen evolution reaction (equation 1) in alkaline media also contributes largely to this overpotential, compared to the cathodic $\mathrm{H}_{2}$ evolution (equation 2).

$2 \mathrm{OH}^{-} \rightarrow 1 / 2 \mathrm{O}_{2}+\mathrm{H}_{2} \mathrm{O}+2 \mathrm{e}^{-}$

$2 \mathrm{H}_{2} \mathrm{O}+2 \mathrm{e}^{-} \rightarrow \mathrm{H}_{2}+2 \mathrm{OH}^{-}$

Therefore, in reality, cell potentials over $1.5 \mathrm{~V}$ should be applied to overcome the thermodynamic and kinetic limitations and to produce significant amounts of hydrogen. Furthermore, the electrical current produced by water electrolysis is directly related to the production rate of pure hydrogen (equation 3, Faraday's law). Consequently, the power input to produce $\mathrm{H}_{2}$, which is directly related to the applied potential (equation 4) is quite high and not compatible with an efficient energy saving strategy.

$\mathrm{nH}_{2}=\mathrm{Ix}(2 \mathrm{~F})^{-1}$

where $\mathrm{nH}_{2}$ is the $\mathrm{H}_{2}$ production rate in mol $_{2} \mathrm{~s}^{-1}$, I (A) the obtained current upon the application of a cell potential, and F the Faraday's constant.

PowerWatts $=I \times V_{\text {cell }}$

where Power is power input (W) and $\mathrm{V}_{\text {cell }}$ the cell potential (V).

One alternative, that is gaining growing attention in the last decades, is to substitute water in the anodic compartment by an organic feedstock. From a thermodynamic point of view, the electro-oxidation of organic molecules takes place at much lower potentials compared to the above-mentioned oxygen evolution reaction. Hence, in theory, the energy input to produce hydrogen by the electrolysis of such organic compounds is much lower. This technology has been thoroughly studied mainly for alcohols, such as methanol [11-14], ethanol [15-20] and glycerol [21,22]. A very interesting review article recently published by Miller et al. [23] analyzed the feasibility of such technology aiming its exploitation considering, among other 
factors, the cost of the alcohol. For instance, for ethanol (bio-ethanol), they concluded that this process could be convenient if: i) the alcohol is completely electro-oxidized at the anode to maximize the electron transfer and therefore the production of hydrogen (which is usually not the case due to the kinetic limitations of current catalysts to cleave the C-C bonds [24-26]), ii) if the by-products of the alcohol oxidation have an added value (which is the case according to recent publications [27]), and iii) if the feedstock is available at a much lower prize, which can be the case if such feedstock is a waste.

This study is focused on the last alternative. Indeed, the thermodynamics also predict that the electrolysis of organic wastes can produce hydrogen at lower overpotentials compared to water electrolysis, as in the case of alcohols. In addition, this technology could valorize feedstocks of organic wastes that are usually incinerated to produce heat, with the subsequent production of hazardous pollutants. For instance, few recent works focused on the valorization of plasticwastes via electrolysis for hydrogen production [28,29]. On the other hand, the number of publications dealing with the electrolysis of lignin is exponentially increasing in the last years [30-42]. Lignin is a massive bio-polymer waste usually produced after the treatment of the socalled black liquors generated by the pulping Kraft industry. The transformation of lignin into sustainable chemicals and green hydrogen is therefore of paramount importance. In this sense, we recently published a study dealing with the direct electrolysis of lignin in an Anion Exchange Membrane (AEM) electrolyser in a continuous flow over noble-metal based anodes (PtRu) [43]. We clearly demonstrated that pure $\mathrm{H}_{2}$ can be produced at low cell potentials. However, the overall performance of the electrolysis cell was low due to sluggish kinetics towards lignin electro-oxidation. Then, aiming for a better understanding of the mechanism of this electrochemical reaction, we investigated the electro-oxidation of a model molecule (2phenoxyethanol), which is representative of one of the main sub-structures of lignin: the $\beta$-O4 quintessential [44]. We concluded that the electro-oxidation of PtRu electrodes is mainly 
limited to the oxidation of the terminal hydroxyl function $(-\mathrm{OH})$ towards the carboxylic acid ($\mathrm{COOH}$ ), and that those electrodes were very prone to deactivation probably due to the strong chemisorption of some reaction intermediates. We believe therefore that PtRu electrodes should be substituted by either more active or at least less expensive anode materials.

Several publications have pointed out a significant performance of nickel-based electrodes for lignin electrolysis [32-34,37,41,42,45-47]. $\mathrm{Ni}$ is a non-precious/non-expensive material with high corrosion stability in alkaline media, and is commonly used for water electrolysis. In this sense, the key Ni species to catalyze the oxygen evolution reaction have been identified as $\mathrm{NiOOH}[48,49]$. However, such active Ni species were only observed at high cell potentials (over 1.2 V), where water electrolysis can also occur. Nevertheless, a few studies claimed that lignin could be electrolyzed at lower potentials $[37,47]$. However, due to the complexity of the lignin bio-polymer, it is still unclear under those reaction conditions what the nickel active species are, and the main sub-structures or chemical links of lignin cleaved. Hence, the aim of this work is to get more insights into the electrochemical performance of a Ni-based anodic catalyst for the electro-oxidation of both, lignin and 2-phenoxyethanol, where the latter was used as a representative of the $\beta-\mathrm{O}-4$ substructure of lignin. 


\section{Experimental}

\subsection{Catalyst synthesis and characterization}

The objective was to prepare a $\mathrm{Ni} / \mathrm{C}$ catalyst $(20 \% \mathrm{wt}$. Ni) by using the well-known polyol method [27,50]. $\mathrm{Ni}\left(\mathrm{NO}_{3}\right)_{2} \times 6 \mathrm{H}_{2} \mathrm{O}$ (Sigma Aldrich) was used as metal precursor, ethylene glycol (CarlROTH) served as a reducing agent, $\mathrm{NaOH}$ (NORMAPUR) was used to adjust the pH while carbon Vulcan XC-72 (Fuel Cell Store ${ }^{\circledR}$ ) was the catalytic support. Briefly, the metal precursor and ethylene glycol were first stirred together in a beaker until complete dissolution. Then, a strong base (NaOH $0.2 \mathrm{M})$ was added to adjust the $\mathrm{pH}$ to a value of 9 , followed by stirring the solution at $190^{\circ} \mathrm{C}$ for 2 hours. After that, carbon Vulcan XC-72 was added to the solution and further stirred for 48 hours at ambient temperature. The synthesis was followed by filtering and thoroughly washing the obtained product with distillate water. Finally, the obtained powder was dried at $80^{\circ} \mathrm{C}$ in static air.

X-ray diffraction technique was used to identify the structure of the $\mathrm{Ni} / \mathrm{C}$ catalyst. A D8 Advance (BRUKER) instrument equipped with $\mathrm{Cu} \mathrm{K} \alpha$ radiation with $\mathrm{Ni}$ filtered $\mathrm{Cu} \mathrm{K} \alpha$ radiation $(\lambda \mathrm{K} \alpha 1=1.54184 \AA)$ was used. The diffraction intensity as a function of the angle 2 theta was measured between $4^{\circ}$ and $80^{\circ}$, with a 2-theta step of $0.0204^{\circ}$ for $96 \mathrm{~s}$ per point. $\mathrm{N}_{2}$ physisorption was used to measure the specific surface area by the BET (Brunauer-EmmettTeller) method. For this purpose, the sample was pretreated (by degasification) at $100{ }^{\circ} \mathrm{C}$ overnight (VacPrep 061, Sample Degas System, Micromeritics), followed by $\mathrm{N}_{2}$ physisorption on a TriStar Surface Area and Porosity Analyzer equipment from Micromeritics. The method of Barrett, Joyner, Halenda $(\mathrm{BJH})$ was applied to measure the mean pore diameter and the pore volume of the catalyst. The idea of doing the degasification pretreatment at such low temperature was to avoid any structural change of the catalyst. The thermogravimetric analysis (TGA) was used to follow the thermal oxidation in air of the Ni catalyst. TGA measurements were carried out in a Mettler MX1 instrument. The samples (5-10 mg) were analyzed without 
previous treatment under atmospheric pressure with a flow of synthetic air $\left(30 \mathrm{ml} \mathrm{min}^{-1}\right)$ from room temperature to $900{ }^{\circ} \mathrm{C}$ (heating ramp : $10{ }^{\circ} \mathrm{C} \mathrm{min}^{-1}$ ) followed by a steady step $(15 \mathrm{~min})$ at this temperature. Transmission electron microscopy (TEM) was performed in a JEOL 2010 $\mathrm{LaB}_{6}$ instrument with $200 \mathrm{kV}$ acceleration voltage. Prior to the measurements, a dispersion of the catalyst in ethanol was deposited on standard holey carbon-covered copper TEM grids. The X-ray photoelectron spectroscopy (XPS) was used to determine the surface elemental information of the as-prepared catalyst. The XPS spectra of the solids were carried out with a Kratos Axis Ultra DLD spectrometer equipped with a hemispherical electron analyzer, using a monochromatic $\mathrm{Al} \mathrm{K \alpha}(1486.6 \mathrm{eV}) \mathrm{X}$-ray source, operating at $225 \mathrm{~W}, 15 \mathrm{~mA}$ and $15 \mathrm{kV}$. Survey spectra were recorded for all samples with a pass energy of $160 \mathrm{eV}, 100 \mathrm{~ms}$ of dwell time and $1.0 \mathrm{eV}$ step. High-resolution spectra were recorded with a $40 \mathrm{eV}$ pass energy, dwell time of 200 $\mathrm{ms}$ and $0.1 \mathrm{eV}$ step in the $\mathrm{Ni} 2 \mathrm{p}_{3 / 2,1 / 2}, \mathrm{O} 1 \mathrm{~s}$ and $\mathrm{C} 1 \mathrm{~s}$ regions. The binding energy of the $\mathrm{C} 1 \mathrm{~s}$ peak at $284.8 \mathrm{eV}$ was taken as an internal standard for the charge correction of spectra. The CasaXPS software was used for data treatment.

\subsection{Electrochemical experiments}

The as-prepared $\mathrm{Ni} / \mathrm{C}$ material was used as anodic electrocatalyst. To prepare the electrode, the catalyst powder was dispersed in a solution of 2-propanol and further sprayed on a carbon cloth (with $410 \mu \mathrm{m}$ thick microporous layer, FuelCellStore ${ }^{\circledR}$ ) with an aerograph under heating at 60 ${ }^{\circ} \mathrm{C}$ to evaporate the alcohol solvent. The electrode was then dried at $80{ }^{\circ} \mathrm{C}$ for 3 hours.

The electrochemical experiments were performed in both, a 3-electrode electrochemical cell, and an AEM electrolyzer. In the 3-electrode cell, preliminary electrochemical experiments with the 2-phenoxyethanol model molecule (volume of the solution: $150 \mathrm{~mL}, 10 \mathrm{~g} \mathrm{~L}^{-1}$ of 2-PE in 1 $\mathrm{M} \mathrm{KOH}$ ) and $\mathrm{KOH} 1 \mathrm{M}$ (volume of the solution: $150 \mathrm{~mL}$ ) were performed. A Pt mesh (geometric surface $4 \mathrm{~cm}^{2}$ ) was used as a counter electrode, and $\mathrm{Hg} / \mathrm{HgO}$ served as a reference 
electrode. The $\mathrm{Ni} / \mathrm{C}$ catalyst prepared by the polyol method impregnated on carbon cloth $(0.75$ $\mathrm{mg}_{\text {catalyst }} \mathrm{cm}^{-2}$, geometric surface $4 \mathrm{~cm}^{2}$ ) was used as an anode. The cell was heated by means of externally controlled water circulation in an outer chamber up to $65^{\circ} \mathrm{C}$. Before (and during) each experiment, the system was purged with $\mathrm{N}_{2}$ for 15 minutes to eliminate the presence of $\mathrm{O}_{2}$ from the air.

Regarding the AEM electrolyser, the electrochemical experiments were performed in a commercial Polymer Electrolyte Membrane (PEM) cell (Baltic fuel cells $®)$ ). The cell consisted of an anode and a cathode separated by an alkaline polymeric membrane. Anode/membrane/cathode were put between two Teflon gaskets which ensured the sealing of the cell. Graphitic bi-polar plates with parallel grooves (flow channels) were used as current collectors. The system was equipped with a temperature controller. The synthesized $\mathrm{Ni} / \mathrm{C}$ catalyst impregnated on carbon cloth $\left(1 \mathrm{mg}_{\text {catalyst }} \mathrm{cm}^{-2}\right)$, was used as anode. A commercial $\mathrm{Pt} / \mathrm{C}$ cathode $\left(0.2 \mathrm{mg}_{\text {catalyst }} \mathrm{cm}^{-2}, 20 \%\right.$ wt. Pt, Fuel Cell Store $\left.\circledR\right)$ was impregnated on the same carbon cloth with the same method. Both electrodes had a geometric surface of $25 \mathrm{~cm}^{2}$. An alkaline $\left(\mathrm{OH}^{-}\right)$polymeric membrane (Fumapem FAA-3-50 ®) with 45-50 $\mu \mathrm{m}$ thickness was used as electrolyte. The membrane was pretreated in $1 \mathrm{M} \mathrm{KOH}$ aqueous solution for 24 hours at room temperature to exchange $\mathrm{Br}^{-}$groups into $\mathrm{OH}^{-}$groups.

In the AEM configuration, the electrolysis was performed in a recirculation mode. The anode was supplied with 3 different solutions for further comparison: i) alkaline solution of 2phenoxyethanol model molecule (volume of the solution: $30 \mathrm{~mL}, 10 \mathrm{~g} \mathrm{~L}^{-1}$ of 2-PE, $1 \mathrm{M} \mathrm{KOH}$, flow: $1.8 \mathrm{~mL} \mathrm{~min}^{-1}$ ), ii) with alkali (Kraft) lignin (Sigma Aldrich, volume of the solution: 30 $\mathrm{mL}, 10 \mathrm{~g} \mathrm{~L}^{-1}$ of lignin, $1 \mathrm{M} \mathrm{KOH}$, flow: $1.8 \mathrm{~mL} \mathrm{~min}^{-1}$ ), or iii) with $1 \mathrm{M} \mathrm{KOH}$ solution (volume of the solution: $30 \mathrm{~mL}, 1.8 \mathrm{~mL} \mathrm{~min}^{-1}$ ), in the absence of any other organic molecules. For cyclic voltammetry experiments, the cathode was always fed with the same $1 \mathrm{M} \mathrm{KOH}$ solution (volume of the solution: $200 \mathrm{~mL}$, flow: $1.8 \mathrm{~mL} \mathrm{~min}^{-1}$ ). For the chronoamperometry experiments, 
the anode was supplied with the three molecules (2-PE, lignin and $\mathrm{KOH}$ ) previously described, while the cathode was fed with $1 \mathrm{M} \mathrm{KOH}$ aqueous solution (volume of the solution: $30 \mathrm{~mL}, 1.8$ $\left.\mathrm{mL} \min ^{-1}\right)$. Prior to every electrochemical experiment, a chronoamperometry at $1.6 \mathrm{~V}$ was applied to the system for 30 min to remove any undesirable products adsorbed on the catalytic surface. This step was realized with $\mathrm{KOH} 1 \mathrm{M}\left(30 \mathrm{~mL}, 1.8 \mathrm{~mL} \mathrm{~min}^{-1}\right)$ on the anode and $\mathrm{KOH}$ $1 \mathrm{M}\left(200 \mathrm{~mL}, 1.8 \mathrm{~mL} \mathrm{~min}{ }^{-1}\right)$ on the cathode. Anode and cathode liquid flow-rates were controlled with a peristaltic pump. A Potentiostat-galvanostat (Origalys ${ }^{\circledR}$ ) was used to polarize the cell.

On the other hand, as in our previous study [29], the composition of the gas produced at the cathode was online recorded during the cyclic voltammetry experiments in the AEM configuration with a quadrupole mass spectrometer (Portable Quadrupole MS, Aspec). The QMS operated under vacuum $\left(\sim 1.3 \times 10^{-6} \mathrm{mbar}\right)$, evacuated by a $70 \mathrm{~L} \mathrm{~s}^{-1}$ turbo molecular drag pump combined with a backing pump. Together with $\mathrm{H}_{2}(\mathrm{~m} / \mathrm{z}=2 \mathrm{amu})$, the eventual presence of the following compounds: $\mathrm{H}_{2} \mathrm{O}(\mathrm{m} / \mathrm{z}=18 \mathrm{amu}), \mathrm{N}_{2}(\mathrm{~m} / \mathrm{z}=28 \mathrm{amu}), \mathrm{O}_{2}(\mathrm{~m} / \mathrm{z}=32 \mathrm{amu})$ and $\mathrm{CO}_{2}(\mathrm{~m} / \mathrm{z}=44 \mathrm{amu})$ was also monitored. The gas from the cathodic compartment was mixed with a constant flow of $\mathrm{He}$ inert gas $\left(33 \mathrm{~mL} \mathrm{~min}^{-1}\right)$ and further introduced into the QMS device for the analysis. $\mathrm{H}_{2}$ was the only gas detected. 


\section{Results and discussion}

\subsection{Catalyst characterization}

First of all, the as-prepared powder catalyst was characterized by a wide variety of techniques in order to identify the main nickel species that will eventually participate in the electrooxidation of lignin and the $\beta-\mathrm{O}-4$ model molecule (2-phenoxyethanol). The X-ray diffraction (XRD) technique was used to study the crystalline structure of the $\mathrm{Ni} / \mathrm{C}$ catalyst. Fig. 1a shows the XRD patterns for the catalyst as well as for the commercial Vulcan XC-72 carbon support. For the latter, diffraction peaks at $2 \theta \sim 25^{\circ}$ and $43^{\circ}$ where observed, in good agreement with previous studies [20,51]. With regards to the catalyst, three additional peaks were obtained at $10.1^{\circ}, 34^{\circ}$ and $60^{\circ}$. The best suitable pattern was found to be $\alpha-\mathrm{Ni}(\mathrm{OH})_{2}$, since some of the characteristic peaks for $\alpha-\mathrm{Ni}(\mathrm{OH})_{2}$ are $11.3^{\circ}, 33.4^{\circ}$ and $60.0^{\circ}$ which correspond to $(003),(101)$ and (110) interplanar distances (JCPDS NO. 38-0715, rhombohedral structure). These results are in good agreement with a previous study by Tang et al. [51], where a $\alpha-\mathrm{Ni}(\mathrm{OH})_{2} / \mathrm{Vulcan}$ XC-72 composite was prepared by a different synthetic route, but still using common precursors (such as ethylene glycol and $\mathrm{NaOH}$ ). The polyol synthetic route usually leads to the production of reduced metals supported on carbon when noble metals are used [27,50]. However, the higher tendency of nickel to get oxidized in an alkaline environment probably explains the formation of the $\alpha-\mathrm{Ni}(\mathrm{OH})_{2}$ crystalline phase. In this sense, Movil et al. [37] used a modified polyol synthetic method for the preparation of $\mathrm{Ni} / \mathrm{C}$ catalyst (also for lignin electro-oxidation) and also observed some XRD peaks corresponding to an oxidized state of $\mathrm{Ni}(\mathrm{NiO})$. In addition, it is worth to note that the peaks obtained in the XRD spectra were broad, suggesting that the catalyst exhibits an overall low crystallinity ( $58 \%$ according to the Diffract-EVA software). This is probably because the catalyst was not annealed at high temperatures. The average crystallite size of $\alpha-\mathrm{Ni}(\mathrm{OH})_{2}$ estimated from the (003) diffraction peak using Scherrer's formula was $\sim 3 \mathrm{~nm}$. Therefore, the results obtained by XRD seem to indicate that the synthetic route 
chosen in this study led to the production of mainly $\alpha-\mathrm{Ni}(\mathrm{OH})_{2}$ supported on the Vulcan XC72 carbon. More importantly, the catalyst exhibit very promising structural properties, with nanometric crystallites of $\alpha-\mathrm{Ni}(\mathrm{OH})_{2}$ despite the high $\mathrm{Ni}$ loading.

The $\mathrm{N}_{2}$-physisorption experiments show typical type IV with the $\mathrm{H} 3$ hysteresis loop type (at a relative pressure of $\sim 0.5-1$ bar) $\mathrm{N}_{2}$ adsorption/desorption isotherms (not shown here). Such profile is indicative of a mesoporous structure, as expected. The BET specific surface area obtained was $207 \mathrm{~m}^{2} \mathrm{~g}^{-1}$. A value of $235 \mathrm{~m}^{2} \mathrm{~g}^{-1}$ was previously reported for a similar carbon support (Vulcan XC 72 R) [52], suggesting that the high Ni loading (20\% wt) did not block the mesopores. In addition, the average pore size and the pore volume were found to be $8.9 \mathrm{~nm}$ and $0.3 \mathrm{~cm}^{2} \mathrm{~g}^{-1}$, respectively. These results confirmed the mesoporous nature of the catalyst, which is relevant to favor an efficient diffusion of the reactants to the nickel active sites.

Fig. 1b shows the thermogravimetric curves for both, the catalyst and the carbon support. Regarding the Vulcan XC-72 material, a drastic weight loss was observed after $600{ }^{\circ} \mathrm{C}$, leading to the total depletion of the carbon support. This is expected, considering its oxidation in a highly oxidizing reaction atmosphere. Using these results as a baseline, the nickel loading on the catalyst can be easily obtained by comparing the final weight loss of such material under similar conditions. In this sense, the first part of the TGA profile obtained for the $\mathrm{Ni} / \mathrm{C}$ catalyst (Temperature $<500{ }^{\circ} \mathrm{C}$ ) was very similar to those previously described by $\mathrm{Yu}$ et al. [53] and Abbas et Jung [54] for $\alpha-\mathrm{Ni}(\mathrm{OH})_{2}$ materials. The first important weight loss observed $(\sim 12 \%$ of the total weight, below $270{ }^{\circ} \mathrm{C}$ ) could be ascribed, according to ref. [54], to the dehydration of adsorbed water on $\alpha-\mathrm{Ni}(\mathrm{OH})_{2}$, together with the phase transformation of nickel hydroxide to nickel oxide. No further significant weight losses were observed in refs. [53] and [54] after 270 ${ }^{\circ} \mathrm{C}$. However, in the present study, a progressive loss was obtained as the temperature increased from $270{ }^{\circ} \mathrm{C}$. The final steady state was obtained at lower temperatures compared to that for the total oxidation of the carbon support. It seems to indicate that the nickel species catalysed the 
oxidation of carbon. The fact that the first part of our TGA profile depicted an important weight loss below $270{ }^{\circ} \mathrm{C}$ confirms, as previously described in the XRD results, the presence of $\alpha$ $\mathrm{Ni}(\mathrm{OH})_{2}$ in the as-prepared powder catalyst. The final weight loss corresponds to $\sim 78 \%$. Thus, the mass fraction of $\alpha-\mathrm{Ni}(\mathrm{OH})_{2}$ and XC-72 in $\alpha-\mathrm{Ni}(\mathrm{OH})_{2} / \mathrm{XC}-72$ catalyst is $\sim 22 \%$ and $\sim 78 \%$ respectively, as expected considering the initial targeted concentration $(20 \% \mathrm{wt}$. Ni).

The catalyst was further characterized by X-ray photoelectron spectroscopy (XPS). Fig. 2 a and b present the XPS detailed spectra of the Ni 2p $p_{3 / 2}$ and $\mathrm{O} 1 \mathrm{~s}$ binding energy levels and their satellites, respectively. According to literature [55-57], the deconvoluted Ni $2 \mathrm{p}_{3 / 2}$ peaks could be attributed to $\mathrm{Ni}(\mathrm{OH})_{2}$ (lowest binding energy) and $\mathrm{NiOOH}$ species (highest binding energy), (Fig. 2a). With regards to the $\mathrm{O} 1 \mathrm{~s}$ spectra (Fig. 2b), the lowest binding energies at $532.9 \mathrm{eV}$ and $534.5 \mathrm{eV}$ could be associated with lattice oxygen in $\mathrm{NiO}$ and $\mathrm{Ni}-\mathrm{OH}$, respectively. The highest binding energy peak at $536.2 \mathrm{eV}$ could be assigned to adsorbed water [55].

Transmission Electronic Microscopy (TEM) was used to observe the presence of nickel particles on the carbon support (Fig. 2 c-d). In the selected pictures, small filament-like Nibased nanoparticles were clearly observed supported on carbon. The length of those filaments varied, but their elevation was $\sim 2-3 \mathrm{~nm}$, in good agreement with the crystallite size calculations performed from the XRD analysis. In addition, Fast Fourier Transform (FFT) analysis of the electrons diffraction was performed on several selected particles and the spacing of the crystal planes was calculated (Fig. S1). The results reasonably fit with a NiO structure (Fig. S1), while $\alpha-\mathrm{Ni}(\mathrm{OH})_{2}$ was detected by XRD.

To summarize the characterization results, we could first conclude that the as-prepared catalyst is composed, regardless of its high metal loading ( $20 \%)$, of very small nickel-based nanoparticles dispersed on the surface of a mesoporous carbon support. As a matter of fact, this is a very important feature, since small nanoparticles are prone to exhibit high electrocatalytic performance. In the long run, metal nanoparticle-based electrocatalysts are more attractive than 
large/unsupported metal electrodes (commonly used for water electrolysis), since the metal dispersion is higher, leading therefore to an enhanced metal utilization in practical terms. According to XRD performed at room temperature in air, the main nickel crystalline phase is $\alpha-\mathrm{Ni}(\mathrm{OH})_{2}$. The results obtained by XPS also suggested the presence of such phase. However, with the TEM under ultra-high vacuum conditions, we were only able to confirm the presence of $\mathrm{NiO}$ small nanoparticles. We believe that $\alpha-\mathrm{Ni}(\mathrm{OH})_{2}$ is most likely fully or partially dehydrated to $\mathrm{NiO}$ under the high-vacuum and the electron beam required to perform the tests in the TEM apparatus, although further experiments should be performed to verify this issue. In any case, the electrolysis experiments will be performed in a strong alkaline environment. Therefore, we can consider that the majority of the catalyst is based on $\alpha-\mathrm{Ni}(\mathrm{OH})_{2}$ nanoparticles supported on the Vulcan XC-72 carbon material in agreement with Li et al. [58] who suggested that $\mathrm{Ni}(\mathrm{OH})_{2}$ was spontaneously formed when a metallic $\mathrm{Ni}$ electrode was placed into the alkaline electrolyte.

\subsection{Electrochemical activity}

First of all, the electrochemical activity of the Ni/C-based electrode was studied on a 3-electrode cell. Fig. 3a-c show the cyclic voltammetry experiments for alkaline water and 2-PE electrolysis from -800 to $600 \mathrm{mV}$ vs $\mathrm{Hg} / \mathrm{HgO}$ at $60{ }^{\circ} \mathrm{C}\left(10\right.$ cycles, sweep scan $\left.20 \mathrm{mV} \mathrm{sec}{ }^{-1}\right)$. Figure $3 \mathrm{a}$ presents three cycles $\left(2^{\text {nd }}, 5^{\text {th }}\right.$ and $\left.10^{\text {th }}\right)$ for water electrolysis (only $1 \mathrm{M} \mathrm{KOH}$ solution was introduced in the electrochemical cell). Bode's diagram has long been adopted to illustrate the Ni-based redox transformations during alkaline water electrolysis [48,49]. According to it, the $\alpha-\mathrm{Ni}(\mathrm{OH})_{2}$ initial phase would be transformed to more stable $\beta-\mathrm{Ni}(\mathrm{OH})_{2}$ (equation 5) through an aging period.

$\alpha-\mathrm{Ni}(\mathrm{OH})_{2} \rightarrow \beta-\mathrm{Ni}(\mathrm{OH})_{2}$

The latter is then oxidized to the oxy(hydroxide) phase $(\beta-\mathrm{NiOOH})$ in alkaline media following the reaction (6): 
$\beta-\mathrm{Ni}(\mathrm{OH})_{2}+\mathrm{OH}^{-} \rightarrow \beta-\mathrm{NiOOH}+\mathrm{H}_{2} \mathrm{O}+\mathrm{e}^{-}$

On the other hand, $\alpha-\mathrm{Ni}(\mathrm{OH})_{2}$ could directly transform to $\gamma$-NiOOH. The Ni oxy-hydroxide form is reported to be extremely active for the oxygen evolution reaction (equation 1) which normally occurs at E $>1.5 \mathrm{~V}$ vs RHE [59].

While $\beta-\mathrm{NiOOH}$ is generally considered as the active phase for the oxygen evolution reaction [49], $\gamma$-NiOOH has also been proposed to be efficient by Bediako et al. [60]. The formation of $\beta-\mathrm{Ni}(\mathrm{OH})_{2}$ seems to be irreversible (phase transition), while the production of $\mathrm{NiOOH}$ phases is a reversible step $[61,62]$.

As it was previously mentioned in section 3.1 , we consider that $\alpha-\mathrm{Ni}(\mathrm{OH})_{2}$ is most likely the most abundant nickel species in the as-prepared anodic catalyst developed in this study by the polyol method. Thus, considering that the transformation into $\beta-\mathrm{Ni}(\mathrm{OH})_{2}$ is a phase transition process with no charge transfer, two oxidation peaks are expected during the forward scan in the cyclic voltammetry experiment, corresponding to the formation of $\mathrm{NiOOH}$ active species, and the oxygen evolution reaction. In addition, a reduction peak (normally attributed to the reduction of $\mathrm{NiOOH}$ to $\left.\beta-\mathrm{Ni}(\mathrm{OH})_{2}\right)$ is expected at $\sim 0,3 \mathrm{~V}$ vs $\mathrm{Hg} / \mathrm{HgO}$ during the backward scan [49,61-63]. However, in Fig. 3a, with an onset potential over $0.4 \mathrm{~V}$ vs $\mathrm{Hg} / \mathrm{HgO}$, only one oxidation peak is observed during the forward scan, and a strong reduction peak at $\sim 0.28 \mathrm{~V}$ vs $\mathrm{Hg} / \mathrm{HgO}$ was observed during the reduction scan. Therefore, we suggest that the drastic current increase during the forward scan is due to both, the electro-oxidation of $\mathrm{Ni}(\mathrm{OH})_{2}$ to $\mathrm{NiOOH}$ species (reversible process), together with the oxygen evolution reaction. Finally, a smaller reduction peak appeared at $\sim-0.35 \mathrm{~V}$ vs $\mathrm{Hg} / \mathrm{HgO}$. According to Chelaghmia et al. [64], it could be attributed to the reduction of nickel oxide species. These NiO species could be eventually formed from $\alpha-\mathrm{Ni}(\mathrm{OH})_{2}$ [62]. All in all, these results suggest that the main nickel active species in the anodic catalyst are $\mathrm{Ni}(\mathrm{OH})_{2}$ and $\mathrm{NiOOH}$ (and $\mathrm{NiO}$ in a minor extent). Further in-situ studies should be performed to determine the exact nature of the active Ni species. 
A similar cyclic voltammetry experiment $(10$ cycles, $-800 \mathrm{mV}-600 \mathrm{mV}$ vs $\mathrm{Hg} / \mathrm{HgO}$, sweep scan $20 \mathrm{mV} \mathrm{sec}-1,60{ }^{\circ} \mathrm{C}$ ) was performed to study the alkaline electro-oxidation of 2phenoxyethanol (2-PE) on the Ni/C-based electrode (Fig. 3b). With an onset potential over 0.4 $\mathrm{V}$ vs $\mathrm{Hg} / \mathrm{HgO}$, the oxidation of the model molecule starts at the same potential than that for the alkaline water electrolysis system. In addition, slightly higher current densities were achieved. This suggests that the active phase for the electro-oxidation of 2-PE is the same than that for the oxygen evolution reaction (i.e. $\mathrm{NiOOH}$ ). However, the reduction peaks previously observed at $\sim 0.28 \mathrm{~V}$ and to a lesser extent at $\sim-0.35 \mathrm{~V}$ vs $\mathrm{Hg} / \mathrm{HgO}$ were negligible. This indicates that $\mathrm{NiOOH}$ species were consumed during the electro-oxidation process. A very similar trend was observed in previous studies dealing with the alkaline electro-oxidation of ethanol on nickelbased electrodes [65]. Most studies dealing with the alkaline electro-oxidation of methanol $[55,66,67]$ and ethanol $[65,68]$ agree with a general mechanism where, first of all, the electrochemical conversion of nickel to active nickel oxidized species (NiOOH) takes place. In a second step, these active nickel species promote the oxidation of the alcohol (e.g., for ethanol, equation $7[65])$.

$$
4 \beta-\mathrm{NiOOH}+\mathrm{CH}_{3} \mathrm{CH}_{2} \mathrm{OH}+\mathrm{OH}^{-} \rightarrow 4 \beta-\mathrm{Ni}(\mathrm{OH})_{2}+\mathrm{CH}_{3} \mathrm{COO}^{-}
$$

The following features are worth mentioning: i) first of all, this second reaction does not involve an electron-transfer from the organic molecule to the anode. In other words, this is a chemical process and, in general terms, is expected to exhibit slower kinetics compared to the first step. ii) in all the references above mentioned for methanol and ethanol, it is expected that the alcohol oxidation is limited to the formation of the carboxylic acid function. iii) the active $\mathrm{NiOOH}$ species are continuously consumed (reduced) with the alcohol, but at the same time such $\mathrm{NiOOH}$ species will be continuously generated in the range of electrical potentials under study, resulting in a system that is "autocatalytic". 
In our previous study dealing with the alkaline electro-oxidation of 2-PE with PtRu electrodes [44] we observed that this molecule exhibited a similar electro-oxidation mechanism than that for alcohols. This seems to be the case also in the present study. Therefore we suggest, in view of the cyclic voltammetry experiments (Fig. 3b), that after the formation of the active $\mathrm{NiOOH}$ species in the electrode, the 2-PE undergoes an electro-oxidation that mostly affects the terminal -OH bonds, leading to the formation of the 2-phenoxyacetic carboxylic acid (equation 8).

$$
4 \mathrm{NiOOH}+\mathrm{RCH}_{2} \mathrm{OH}+\mathrm{OH}^{-} \rightarrow 4 \mathrm{Ni}(\mathrm{OH})_{2}+\mathrm{RCOO}^{-}
$$

In addition, a slight deactivation was observed during the voltammetry experiments. It could be attributed, as we suggested in our previous work [44], to the strongly chemisorbed reaction intermediates (e.g., aldehydes) produced during the oxidation of the model molecule, which gradually block the surface.

All in all, by comparing the $10^{\text {th }}$ cycle of the voltammetry experiments for water and 2-PE electrolysis (Fig. 3c), we can summarize that, with similar onset potentials for both molecules, the active phase required to initiate the electro-oxidation processes is the same Ni species, i.e. $\mathrm{NiOOH}$. These latter are not consumed during the oxygen evolution process. However, they might be chemically reversibly reduced into $\mathrm{Ni}(\mathrm{OH})_{2}$ with the 2-PE model molecule (equation 8), which explains why the reduction peaks observed during the backward scan for water electrolysis, disappeared for 2-PE electrolysis.

In order to assess the performance of the nickel-based electrode in steady state conditions with both molecules, chrono-amperometry experiments were performed at the same reaction temperature $\left(60^{\circ} \mathrm{C}\right)$ and upon the application of three different constant potentials: $400 \mathrm{mV}$, $500 \mathrm{mV}$ and $600 \mathrm{mV}$ vs $\mathrm{Hg} / \mathrm{HgO}$ (Fig. 3d). The idea was to evaluate the activity below and above the onset potential observed in the cyclic voltammetry experiments (Fig. 3a-c). Hence, at $400 \mathrm{mV}$, no activity was observed for either water or 2-PE electro-oxidation. However, upon 
the application of higher potentials, an important activity was observed, with a higher performance for 2-PE electrolysis, in good agreement with the voltammetry experiments. In addition, as we described in previous studies [44], together with the electro-oxidation processes at the anode, the hydrogen evolution reaction takes place at the cathode (equation 2).

Considering a selective $\mathrm{OH}^{-}$conductivity of the alkaline polymeric membrane, the hydrogen production can be directly calculated using Faraday's law (equation 3). Therefore, as observed in Fig. 3d, the hydrogen production was significantly higher (gain of around 25\%) in the presence of the 2-PE model molecule. However, as opposed to the voltammetry experiments, no important catalyst deactivation was observed during these steady tests. As a matter of fact, the produced current (and therefore the hydrogen production) gradually increased with time in the case of 2-PE electro-oxidation at $600 \mathrm{mV}$ vs $\mathrm{Hg} / \mathrm{HgO}$ electrode. We observed a similar behavior in previous studies dealing with ethanol electrolysis $[15,20]$, and it was attributed to the gradual electro-oxidation of potentially poisoning species (e.g., aldehydes).

All these electrochemical experiments showed therefore that the electro-oxidation of the 2-PE model molecule on nickel-based electrodes takes place in the same range of potentials than that for water electrolysis (i.e., over $0.4 \mathrm{~V}$ vs $\mathrm{Hg} / \mathrm{HgO}$ ), but leads to a higher production of $\mathrm{H}_{2}$. It suggests that the formation of the $\mathrm{NiOOH}$ phase is required to activate (most likely) the terminal -OH bonds present in the $\beta-\mathrm{O}-4$ linkage. Considering that $\beta-\mathrm{O}-4$ sub-structure represents over $60 \%$ of lignin units, we can expect an important extension of the electro-oxidation of the lignin molecule over this kind of nickel-based electrode, at high cell potentials. However, lignin is also composed of other inter-unit linkages $(\beta-\beta, \beta-5, \beta-1, \alpha-O-4,4-O-5$, etc). Therefore, we will study the performance of the as-prepared catalyst for lignin electrolysis, in comparison with the 2-PE model molecule.

The next series of experiments were performed in an AEM electrolyser. As we discussed in our previous study [44], AEM cells offer unique advantages compared with conventional 3- 
electrode cells, mainly due to the fact that AEM is a compact/robust configuration easy to scale up. This configuration also allows to separate the hydrogen produced at the cathode from the oxidation products at the anode due to the presence of a polymeric membrane between both electrodes. Fig. 4 shows a series of in-situ cyclic voltammetry experiments for water electrolysis (Fig. 4a), 2-PE electrolysis (Fig. 4b) and lignin electrolysis (Fig. 4c) at a constant temperature of $80{ }^{\circ} \mathrm{C}\left(10\right.$ cycles, $\mathrm{V}_{\text {cell }}=0-1.6 \mathrm{~V}$, sweep scan $\left.10 \mathrm{mV} \mathrm{sec}{ }^{-1}\right)$.

The results obtained for both water and 2-PE electrolysis are in good agreement with those previously shown in the 3-electrode configuration (Fig. 3a-c). Therefore, with an onset cell potential $\sim 1.4 \mathrm{~V}$, the current increase during the forward scan could be attributed to the formation of the $\mathrm{NiOOH}$ species which triggers the oxygen evolution reaction (equation 1) (Fig. 4a, water electrolysis) and the alcohol oxidation (equation 8) (Fig. 4b, 2-PE electrolysis). A small peak was also observed during the backward scan for water electrolysis at $\sim 1.3 \mathrm{~V}$, which could be attributed to the reversible reduction of $\mathrm{NiOOH}$ into $\mathrm{Ni}(\mathrm{OH})_{2}$. This peak disappeared in the case of 2-PE electrolysis, due to the consumption of the active $\mathrm{NiOOH}$ species with the model molecule. As expected, the performance was stable for water electrolysis, but a slight deactivation took place in the presence of the model molecule, which could be attributed to the presence of some intermediate poisoning species, as we observed in our previous study with PtRu-based anodes [44]. The most interesting results were obtained for the electrolysis of lignin. As it can be clearly observed in Fig. 4c, at least two different electro-oxidation processes took place during the forward scan, the first one with a much lower onset potential $(\sim 1 \mathrm{~V})$ compared to that of water and 2-PE. Previous studies clearly proved that the electro-oxidation of simpler organic molecules including methanol [55,66,67], ethanol $[65,68]$, glycerol [69] or even n-propylamine, glucose and malonic acid [70] required the formation of $\mathrm{NiOOH}$, as it was the case also in the present study with 2-PE. However, it seems that the first electro-oxidation step for lignin does not require the formation of such Ni species. It implies that a primary 
electrolysis of lignin could be performed with lower energy requirements on this catalytic material. This first oxidation step is overlapped with a second oxidation process, which occurred in a range of potentials compatible with the formation of $\mathrm{NiOOH}$ species. However, the overall current produced under those conditions was also higher with lignin compared to 2PE and water. These results primarily indicate that at low polarizations solely lignin is electrolyzed (since water electrolysis is not thermodynamically possible at those potentials), while at high polarizations both, lignin and water are co-electrolyzed. Therefore, the faradaic efficiency towards lignin electro-oxidation at high potentials is expected to be lower due to the competition with the oxygen evolution reaction (eq. 1), although further analytic experiments should be performed in future studies to assess the extent of each electrochemical process.

Taking into account the electrochemical experiments described in Figs. 3 and 4, we suggest therefore that the electro-oxidation of lignin occurs mainly in two steps, before and after the electrochemical formation of $\mathrm{NiOOH}$ species. In other words, at least two different oxidation processes, catalyzed by two different nickel-based species, take place as a function of the applied potential. Regarding the first oxidation peak, a similar behavior was previously observed by Movil et al. [71] and Parpot et al. [47]. In the former work [71], it was suggested that the oxidation of hydroxyl groups present in the guaiacyl units occurred in this potential range. In the latter study [47], a series of model molecules were used, including guaiacol, eugenol and vanillic alcohol. All these molecules have in common a primary - OH group linked to an aromatic function. It was proposed that these $\mathrm{OH}$ groups were responsible for the first oxidation peak before the formation of $\mathrm{NiOOH}$ species. We believe that those results and the new insights of this study are complementary, and therefore we can propose the following overall reaction model: considering that one of the main nickel species in the as-prepared catalyst is $\alpha-\mathrm{Ni}(\mathrm{OH})_{2}$, as we previously discussed, the irreversible phase transition towards $\beta$ $\mathrm{Ni}(\mathrm{OH})_{2}$ is expected. Before those species evolve into $\mathrm{NiOOH}$, it seems that this $\beta$ nickel 
hydroxide phase has the ability to catalyze the electro-oxidation of primary alcohol groups linked to the aromatic functions. On the other hand, when higher potentials are reached, the $\beta$ $\mathrm{Ni}(\mathrm{OH})_{2}$ species are oxidized into $\mathrm{NiOOH}$, and these species seemed to efficiently catalyze the electro-oxidation of the terminal -OH groups present in the $\beta-\mathrm{O}-4$ link in lignin, which represents a significant fraction of the lignin bio-polymer backbone. The fact that the obtained electrical current upon the application of high potentials was higher for lignin than that for 2$\mathrm{PE}$ also demonstrates that probably other species are oxidized together with the terminal $-\mathrm{OH}$ bonds. Among others, it could be due to the further oxidation of the species primarily oxidized at lower potentials, as suggested in ref. [47].

On the other hand, it is worth noting that the lignin electrolysis undergoes a significant deactivation (Fig. 4c). A similar deactivation phenomenon was related in ref. [47] to the surface poisoning due to the formation of intermediate phenolate radicals from the oxidation of the primary alcohol. This phenomenon, together with the strong adsorption of aldehyde-type species produced at higher potentials, could explain the observed deactivation.

In order to verify the purity of the hydrogen production, during the cyclic voltammetry tests with 2-PE and lignin (Figs. $4 \mathrm{~b}$ and c, respectively), the composition of the gas produced at the cathode was qualitatively measured by mass spectrometry, as we described in our previous study for the electrolysis of a plastic model molecule [29]. Figs. 5a and b show, respectively, the dynamic evolution of $\mathrm{H}_{2}$ and $\mathrm{CO}_{2}$ (in arbitrary units) for 2-PE and lignin. In both cases, $\mathrm{H}_{2}$ was the only gas detected according to our $\mathrm{CO}_{2}$ detection limit of around $50 \mathrm{ppm}$. In addition, the hydrogen production followed exactly the same trend than the electrical current, including the decrease related to the deactivation phenomena. It demonstrates, as expected, that the AEM technology allows to produce pure $\mathrm{H}_{2}$ at the cathode of the cell. In addition, the $\mathrm{H}_{2}$ production peaks in presence of lignin are broader with a shoulder at low potential, which corresponds to the first oxidation peak. 
Finally, following a similar strategy than that for the 3-electrode cell configuration, chronoamperometry tests were performed under the application of constant polarizations before and after the corresponding formation of $\mathrm{NiOOH}$ species. The electrochemical tests were performed with water, 2-PE and lignin under $1.1 \mathrm{~V}, 1.3 \mathrm{~V}$ and $1.5 \mathrm{~V}$ (Fig. 6), and the hydrogen production was calculated according to the Faraday's law (equation 3). Upon the application of 1.1 and 1.3 $\mathrm{V}$, before the formation of $\mathrm{NiOOH}$, only lignin was significantly electrolyzed. However, at 1.5 $\mathrm{V}$, all molecules were electrolyzed, even though the performance for lignin electro-oxidation was initially better than that for 2-PE, which was also higher than water, in good agreement with the cyclic voltammetry experiments. However, as expected according to the previous discussion, the system exhibits an important deactivation in the presence of lignin.

This comprehensive study presents new insights into the electrolysis of lignin with nickel-based catalysts, mainly regarding the active nickel species and the activation of different chemical functions of the lignin molecule. These materials will play a key role in the near future towards the valorization of lignin for the production of hydrogen and other added-value products. Of course, an important issue is the strong deactivation of the catalyst under electrolysis conditions. We believe in this sense that the recent advances performed by the team of J. A. Staser [32$34,37,41]$, dealing with the stabilization of $\mathrm{Ni}$ with other co-metals (e.g., Co, Sn) could overcome that issue, while taking advantage of the outstanding activity of $\mathrm{Ni}$. 


\section{Conclusions}

The goal of this study was to get more insights into the electrolysis of lignin over Ni-based materials in alkaline media. We have prepared, by the polyol method, a carbon-supported $\mathrm{Ni}$ electrocatalyst, containing small filament-like Ni-based nanoparticles mainly exhibiting an $\alpha-$ $\mathrm{Ni}(\mathrm{OH})_{2}$ structure. Complementary electrochemical characterizations have shown that the electro-oxidation of the 2-PE model molecule (representative of the $\beta-\mathrm{O}-4$ linkage in lignin) requires the electrochemical formation of $\mathrm{NiOOH}$ species, which are only produced at high cell potentials compatible with the oxygen evolution reaction. On the other hand, the electrooxidation of lignin undergoes two oxidation steps. The first one, at potentials before the oxygen evolution, was attributed to the cleavage over the $\mathrm{Ni}(\mathrm{OH})_{2}$ catalyst phase of primary $-\mathrm{OH}$ links bonded to the aromatic functions. The second one after the oxygen evolution, also observed for the 2-PE model molecule, could be linked to the oxidation over the $\mathrm{NiOOH}$ phase of the terminal-OH bonds present in the quintessential $\beta-\mathrm{O}-4$ linkage. Regardless the promising performance of the $\mathrm{Ni} / \mathrm{C}$ electrocatalyst towards lignin electro-oxidation, it suffers a significant deactivation, probably due to the chemisorption of phenolic (at low potential) and aldehydetype (at high potential) reaction intermediates. Future comprehensive studies should be performed over bi-metallic Ni-based materials in order to stabilize the activity of $\mathrm{Ni}$.

\section{Acknowledgments}

The authors gratefully acknowledge the French institution "Ecole Urbaine de Lyon" (EUL Institut de Convergences) for funding the Master's grant of Ms. K. Beliaeva and the PhD grant of Mr. N. Grimaldos-Osorio. 


\section{References}

[1] D. Apostolou, G. Xydis, A literature review on hydrogen refuelling stations and infrastructure. Current status and future prospects, Renew. Sustain. Energy Rev. 113 (2019) 109292. https://doi.org/https://doi.org/10.1016/j.rser.2019.109292.

[2] L. Kaiwen, Y. Bin, Z. Tao, Economic analysis of hydrogen production from steam reforming process: A literature review, Energy Sources, Part B Econ. Planning, Policy. 13 (2018) 109-115. https://doi.org/10.1080/15567249.2017.1387619.

[3] S.O. Soloviev, I. V Gubareni, S.M. Orlyk, Oxidative Reforming of Methane on Structured Nickel-Alumina Catalysts: a Review, Theor. Exp. Chem. 54 (2018) 293315. https://doi.org/10.1007/s11237-018-9575-5.

[4] P. Summa, B. Samojeden, M. Motak, Dry and steam reforming of methane. Comparison and analysis of recently investigated catalytic materials. A short review., Polish J. Chem. Technol. 21 (2019) 31-37. https://doi.org/https://doi.org/10.2478/pjct2019-0017.

[5] X. Xiong, C. You, Z. Liu, A.M. Asiri, X. Sun, Co-Doped CuO Nanoarray: An Efficient Oxygen Evolution Reaction Electrocatalyst with Enhanced Activity, ACS Sustain. Chem. Eng. 6 (2018) 2883-2887. https://doi.org/10.1021/acssuschemeng.7b03752.

[6] X. Xiong, Y. Ji, M. Xie, C. You, L. Yang, Z. Liu, A.M. Asiri, X. Sun, MnO2-CoP3 nanowires array: An efficient electrocatalyst for alkaline oxygen evolution reaction with enhanced activity, Electrochem. Commun. 86 (2018) 161-165. https://doi.org/https://doi.org/10.1016/j.elecom.2017.12.008.

[7] Y. Wang, T. Wang, R. Zhang, Q. Liu, Y. Luo, G. Cui, S. Lu, J. Wang, Y. Ma, X. Sun, CuO@CoFe Layered Double Hydroxide Core-Shell Heterostructure as an Efficient Water Oxidation Electrocatalyst under Mild Alkaline Conditions, Inorg. Chem. 59 (2020) 9491-9495. https://doi.org/10.1021/acs.inorgchem.0c01927. 
[8] K. Ayers, N. Danilovic, R. Ouimet, M. Carmo, B. Pivovar, M. Bornstein, Perspectives on Low-Temperature Electrolysis and Potential for Renewable Hydrogen at Scale, Annu. Rev. Chem. Biomol. Eng. 10 (2019) 219-239. https://doi.org/10.1146/annurevchembioeng-060718-030241.

[9] A. Buttler, H. Spliethoff, Current status of water electrolysis for energy storage, grid balancing and sector coupling via power-to-gas and power-to-liquids: A review, Renew. Sustain. Energy Rev. 82 (2018) 2440-2454. https://doi.org/10.1016/j.rser.2017.09.003.

[10] C. Coutanceau, S. Baranton, Electrochemical conversion of alcohols for hydrogen production: a short overview, Wiley Interdiscip. Rev. Energy Environ. 5 (2016) 388400. https://doi.org/10.1002/wene.193.

[11] B. Guenot, M. Cretin, C. Lamy, Clean hydrogen generation from the electrocatalytic oxidation of methanol inside a proton exchange membrane electrolysis cell (PEMEC): effect of methanol concentration and working temperature, J. Appl. Electrochem. 45 (2015) 973-981. https://doi.org/10.1007/s10800-015-0867-3.

[12] C. Lamy, B. Guenot, M. Cretin, G. Pourcelly, A Kinetics Analysis of Methanol Oxidation under Electrolysis/Fuel Cell Working Conditions, ECS Trans. 66 (2015) 112. https://doi.org/10.1149/06629.0001ecst.

[13] A.T. Pham, T. Baba, T. Sugiyama, T. Shudo, Efficient hydrogen production from aqueous methanol in a PEM electrolyzer with porous metal flow field: Influence of PTFE treatment of the anode gas diffusion layer, Int. J. Hydrogen Energy. 38 (2013) 73-81. https://doi.org/10.1016/j.ijhydene.2012.10.036.

[14] S. Uhm, H. Jeon, T.J. Kim, J. Lee, Clean hydrogen production from methanol-water solutions via power-saved electrolytic reforming process, J. Power Sources. 198 (2012) 218-222. https://doi.org/10.1016/j.jpowsour.2011.09.083. 
[15] A. Caravaca, F.M. Sapountzi, A. De Lucas-Consuegra, C. Molina-Mora, F. Dorado, J.L. Valverde, Electrochemical reforming of ethanol-water solutions for pure $\mathrm{H}$ $<$ inf $>2</$ inf $>$ production in a PEM electrolysis cell, Int. J. Hydrogen Energy. 37 (2012). https://doi.org/10.1016/j.ijhydene.2012.03.062.

[16] N. Gutiérrez-Guerra, M. Jiménez-Vázquez, J.C. Serrano-Ruiz, J.L. Valverde, A. de Lucas-Consuegra, Electrochemical reforming vs. catalytic reforming of ethanol: A process energy analysis for hydrogen production, Chem. Eng. Process. Process Intensif. 95 (2015) 9-16. https://doi.org/10.1016/j.cep.2015.05.008.

[17] F. Gutiérrez-Martín, A.B. Calcerrada, A. de Lucas-Consuegra, F. Dorado, Hydrogen storage for off-grid power supply based on solar PV and electrochemical reforming of ethanol-water solutions, Renew. Energy. 147 (2020) 639-649. https://doi.org/10.1016/j.renene.2019.09.034.

[18] E. Ruiz-López, E. Amores, A. Raquel de la Osa, F. Dorado, A. de Lucas-Consuegra, Electrochemical reforming of ethanol in a membrane-less reactor configuration, Chem. Eng. J. 379 (2020) 122289. https://doi.org/10.1016/j.cej.2019.122289.

[19] C. Lamy, T. Jaubert, S. Baranton, C. Coutanceau, Clean hydrogen generation through the electrocatalytic oxidation of ethanol in a Proton Exchange Membrane Electrolysis Cell (PEMEC): Effect of the nature and structure of the catalytic anode, J. Power Sources. 245 (2014) 927-936. https://doi.org/10.1016/j.jpowsour.2013.07.028.

[20] A. Caravaca, A. De Lucas-Consuegra, A.B. Calcerrada, J. Lobato, J.L. Valverde, F. Dorado, From biomass to pure hydrogen: Electrochemical reforming of bio-ethanol in a PEM electrolyser, Appl. Catal. B Environ. 134-135 (2013) 302-309. https://doi.org/10.1016/j.apcatb.2013.01.033.

[21] M. Simões, S. Baranton, C. Coutanceau, Electrochemical valorisation of glycerol, ChemSusChem. 5 (2012) 2106-2124. https://doi.org/10.1002/cssc.201200335. 
[22] S. Kongjao, S. Damronglerd, M. Hunsom, Electrochemical reforming of an acidic aqueous glycerol solution on Pt electrodes, J. Appl. Electrochem. 41 (2011) 215-222. https://doi.org/10.1007/s10800-010-0226-3.

[23] H.A. Miller, A. Lavacchi, F. Vizza, Storage of renewable energy in fuels and chemicals through electrochemical reforming of bioalcohols, Curr. Opin. Electrochem. 21 (2020) 140-145. https://doi.org/https://doi.org/10.1016/j.coelec.2020.02.001.

[24] H. Wang, Z. Jusys, R.J. Behm, Ethanol electrooxidation on a carbon-supported Pt catalyst: Reaction kinetics and product yields, J. Phys. Chem. B. 108 (2004) 1941319424. https://doi.org/10.1021/jp046561k.

[25] E. A. Monyoncho, S. N. Steinmann, C. Michel, E. A. Baranova, T. K. Woo, P. Sautet, Ethanol Electro-oxidation on Palladium Revisited Using Polarization Modulation Infrared Reflection Absorption Spectroscopy (PM-IRRAS) and Density Functional Theory (DFT): Why Is It Difficult To Break the C-C Bond?, ACS Catal. 6 (2016) 4894-4906. https://doi.org/10.1021/acscatal.6b00289.

[26] E.A. Monyoncho, S.N. Steinmann, P. Sautet, E.A. Baranova, C. Michel, Computational screening for selective catalysts: Cleaving the $\mathrm{CC}$ bond during ethanol electro-oxidation reaction, Electrochim. Acta. 274 (2018) 274-278. https://doi.org/10.1016/J.ELECTACTA.2018.04.102.

[27] A. Rodríguez-Gómez, F. Dorado, A. de Lucas-Consuegra, A.R. de la Osa, Influence of $\mathrm{Pt} / \mathrm{Ru}$ anodic ratio on the valorization of ethanol by PEM electrocatalytic reforming towards value-added products, J. Energy Chem. 56 (2021) 264-275. https://doi.org/https://doi.org/10.1016/j.jechem.2020.07.061.

[28] T. Hori, K. Kobayashi, S. Teranishi, M. Nagao, T. Hibino, Fuel cell and electrolyzer using plastic waste directly as fuel, Waste Manag. 102 (2020) 30-39. https://doi.org/10.1016/j.wasman.2019.10.019. 
[29] N. Grimaldos-Osorio, F. Sordello, M. Passananti, P. Vernoux, A. Caravaca, From plastic-waste to H2: Electrolysis of a Poly(methyl methacrylate) model molecule on polymer electrolyte membrane reactors, J. Power Sources. 480 (2020) 228800. https://doi.org/10.1016/j.jpowsour.2020.228800.

[30] S.B. Lalvani, P. Rajagopal, Lignin-Augmented Water Electrolysis, J. Electrochem. Soc. 139 (1992) L1-L2. https://doi.org/10.1149/1.2069212.

[31] S.B. Lalvani, R. Rajagopal, Hydrogen production from lignin-water solution by electrolysis, Holzforschung. 47 (1993) 283-286. https://doi.org/10.1515/hfsg.1993.47.4.283.

[32] F. Bateni, M. NaderiNasrabadi, R. Ghahremani, J.A. Staser, Low-Cost Nanostructured Electrocatalysts for Hydrogen Evolution in an Anion Exchange Membrane Lignin Electrolysis Cell, J. Electrochem. Soc. 166 (2019) F1037-F1046. https://doi.org/10.1149/2.0221914jes.

[33] R. Ghahremani, F. Farales, F. Bateni, J.A. Staser, Simultaneous Hydrogen Evolution and Lignin Depolymerization using NiSn Electrocatalysts in a Biomass-Depolarized Electrolyzer, J. Electrochem. Soc. 167 (2020) 43502.

[34] R. Ghahremani, J.A. Staser, Electrochemical oxidation of lignin for the production of value-added chemicals on Ni-Co bimetallic electrocatalysts, Holzforschung. 72 (2018) $951-960$.

[35] H. Roy Ghatak, Electrolysis of black liquor for hydrogen production: Some initial findings, Int. J. Hydrogen Energy. 31 (2006) 934-938. https://doi.org/10.1016/j.ijhydene.2005.07.013.

[36] H.R. Ghatak, S. Kumar, P.P. Kundu, Electrode processes in black liquor electrolysis and their significance for hydrogen production, Int. J. Hydrogen Energy. 33 (2008) 2904-2911. https://doi.org/10.1016/j.ijhydene.2008.03.051. 
[37] O. Movil, M. Garlock, J.A. Staser, Non-precious metal nanoparticle electrocatalysts for electrochemical modification of lignin for low-energy and cost-effective production of hydrogen, Int. J. Hydrogen Energy. 40 (2015) 4519-4530.

https://doi.org/10.1016/j.ijhydene.2015.02.023.

[38] T. Hibino, K. Kobayashi, M. Nagao, S. Teranishi, Hydrogen Production by Direct Lignin Electrolysis at Intermediate Temperatures, ChemElectroChem. 4 (2017) 30323036. https://doi.org/10.1002/celc.201700917.

[39] A. Caravaca, W.E. Garcia-Lorefice, S. Gil, A. de Lucas-Consuegra, P. Vernoux, Towards a sustainable technology for $\mathrm{H}<\mathrm{inf}>2</ \mathrm{inf}>$ production: Direct lignin electrolysis in a continuous-flow Polymer Electrolyte Membrane reactor, Electrochem. Commun. 100 (2019). https://doi.org/10.1016/j.elecom.2019.01.016.

[40] F. Bateni, M. NaderiNasrabadi, R. Ghahremani, J.A. Staser, Low-cost nanostructured electrocatalysts for hydrogen evolution in an anion exchange membrane lignin electrolysis cell, J. Electrochem. Soc. 166 (2019) F1037-F1046. https://doi.org/10.1149/2.0221914jes.

[41] M. NaderiNasrabadi, F. Bateni, Z. Chen, P.B. Harrington, J.A. Staser, Biomassdepolarized electrolysis, J. Electrochem. Soc. 166 (2019) E317-E322. https://doi.org/10.1149/2.1471910jes.

[42] O. Movil-Cabrera, A. Rodriguez-Silva, C. Arroyo-Torres, J.A. Staser, Electrochemical conversion of lignin to useful chemicals, Biomass and Bioenergy. 88 (2016) 89-96. https://doi.org/10.1016/j.biombioe.2016.03.014.

[43] A. Caravaca, W.E. Garcia-Lorefice, S. Gil, A. de Lucas-Consuegra, P. Vernoux, Towards a sustainable technology for $\mathrm{H} 2$ production: Direct lignin electrolysis in a continuous-flow Polymer Electrolyte Membrane reactor, Electrochem. Commun. 100 (2019) 43-47. https://doi.org/10.1016/j.elecom.2019.01.016. 
[44] K. Beliaeva, M. Elsheref, D. Walden, F. Dappozze, A. Nieto-Marquez, S. Gil, C. Guillard, P. Vernoux, S.N. Steinmann, A. Caravaca, Towards Understanding Lignin Electrolysis: Electro-Oxidation of a $\beta$-O-4 Linkage Model on PtRu Electrodes, J. Electrochem. Soc. 167 (2020) 134511. https://doi.org/10.1149/1945-7111/abb8b5.

[45] S. Stiefel, J. Lölsberg, L. Kipshagen, R. Möller-Gulland, M. Wessling, Controlled depolymerization of lignin in an electrochemical membrane reactor, Electrochem. Commun. 61 (2015) 49-52. https://doi.org/10.1016/j.elecom.2015.09.028.

[46] S. Stiefel, A. Schmitz, J. Peters, D. Di Marino, M. Wessling, An integrated electrochemical process to convert lignin to value-added products under mild conditions, Green Chem. 18 (2016) 4999-5007.

[47] P. Parpot, A.P. Bettencourt, A.M. Carvalho, E.M. Belgsir, Biomass conversion: Attempted electrooxidation of lignin for vanillin production, J. Appl. Electrochem. 30 (2000) 727-731. https://doi.org/10.1023/A:1004003613883.

[48] H. Bode, K. Dehmelt, J. Witte, Zur kenntnis der nickelhydroxidelektrode-I.Über das nickel (II)-hydroxidhydrat, Electrochim. Acta. 11 (1966) 1079-1087. https://doi.org/https://doi.org/10.1016/0013-4686(66)80045-2.

[49] Y. Chen, K. Rui, J. Zhu, S.X. Dou, W. Sun, Recent Progress on Nickel-Based Oxide/(Oxy)Hydroxide Electrocatalysts for the Oxygen Evolution Reaction, Chem. A Eur. J. 25 (2019) 703-713. https://doi.org/10.1002/chem.201802068.

[50] M.J. Torres, P. Sánchez, A. de Lucas-Consuegra, A.R. de la Osa, Electrocatalytic hydrogenation of cinnamaldehyde in a PEM cell: The role of sodium hydroxide and platinum loading, Mol. Catal. 492 (2020) 110936. https://doi.org/https://doi.org/10.1016/j.mcat.2020.110936.

[51] S. Tang, L. Sui, Z. Dai, Z. Zhu, H. Huangfu, High supercapacitive performance of Ni (OH) 2/XC-72 composite prepared by microwave-assisted method, RSC Adv. 5 (2015) 
43164-43171.

[52] T. Maiyalagan, T.O. Alaje, K. Scott, Highly Stable Pt-Ru Nanoparticles Supported on Three-Dimensional Cubic Ordered Mesoporous Carbon (Pt-Ru/CMK-8) as Promising Electrocatalysts for Methanol Oxidation, J. Phys. Chem. C. 116 (2012) 2630-2638. https://doi.org/10.1021/jp210266n.

[53] J. Yu, S. Pan, Y. Zhang, Q. Liu, B. Li, Facile synthesis of monodispersed $\alpha-\mathrm{Ni}(\mathrm{OH}) 2$ microspheres assembled by ultrathin nanosheets and its performance for oxygen evolution reduction, Front. Mater. 6 (2019) 124.

[54] S.A. Abbas, K.-D. Jung, Preparation of mesoporous microspheres of NiO with high surface area and analysis on their pseudocapacitive behavior, Electrochim. Acta. 193 (2016) 145-153. https://doi.org/https://doi.org/10.1016/j.electacta.2016.02.054.

[55] J. Hao, J. Liu, D. Wu, M. Chen, Y. Liang, Q. Wang, L. Wang, X.-Z. Fu, J.-L. Luo, In situ facile fabrication of $\mathrm{Ni}(\mathrm{OH}) 2$ nanosheet arrays for electrocatalytic co-production of formate and hydrogen from methanol in alkaline solution, Appl. Catal. B Environ. 281 (2021) 119510. https://doi.org/https://doi.org/10.1016/j.apcatb.2020.119510.

[56] Y.-J. Shih, Y.-H. Huang, C.P. Huang, Electrocatalytic ammonia oxidation over a nickel foam electrode: Role of $\mathrm{Ni}(\mathrm{OH}) 2(\mathrm{~s})-\mathrm{NiOOH}(\mathrm{s})$ nanocatalysts, Electrochim. Acta. 263 (2018) 261-271. https://doi.org/https://doi.org/10.1016/j.electacta.2018.01.045.

[57] L. Ruan, H. Zhang, M. Zhou, L. Zhu, A. Pei, J. Wang, K. Yang, C. Zhang, S. Xiao, B.H. Chen, A highly selective and efficient $\mathrm{Pd} / \mathrm{Ni} / \mathrm{Ni}(\mathrm{OH}) 2 / \mathrm{C}$ catalyst for furfural hydrogenation at low temperatures, Mol. Catal. 480 (2020) 110639. https://doi.org/https://doi.org/10.1016/j.mcat.2019.110639.

[58] X. Li, F.C. Walsh, D. Pletcher, Nickel based electrocatalysts for oxygen evolution in high current density, alkaline water electrolysers, Phys. Chem. Chem. Phys. 13 (2011) $1162-1167$. 
[59] S. Klaus, Y. Cai, M.W. Louie, L. Trotochaud, A.T. Bell, Effects of Fe Electrolyte Impurities on $\mathrm{Ni}(\mathrm{OH}) 2 / \mathrm{NiOOH}$ Structure and Oxygen Evolution Activity, J. Phys. Chem. C. 119 (2015) 7243-7254. https://doi.org/10.1021/acs.jpcc.5b00105.

[60] D.K. Bediako, B. Lassalle-Kaiser, Y. Surendranath, J. Yano, V.K. Yachandra, D.G. Nocera, Structure-Activity Correlations in a Nickel-Borate Oxygen Evolution Catalyst, J. Am. Chem. Soc. 134 (2012) 6801-6809. https://doi.org/10.1021/ja301018q.

[61] M. Alsabet, M. Grden, G. Jerkiewicz, Electrochemical Growth of Surface Oxides on Nickel. Part 1: Formation of $\alpha-\mathrm{Ni}(\mathrm{OH}) 2$ in Relation to the Polarization Potential, Polarization Time, and Temperature, Electrocatalysis. 2 (2011) 317-330. https://doi.org/10.1007/s12678-011-0067-9.

[62] M. Alsabet, M. Grdeń, G. Jerkiewicz, Electrochemical growth of surface oxides on nickel. Part 3: Formation of $\beta-\mathrm{NiOOH}$ in relation to the polarization potential, polarization time, and temperature, Electrocatalysis. 6 (2015) 60-71.

[63] D.W. Kirk, S.J. Thorpe, H. Suzuki, Ni-base amorphous alloys as electrocatalysts for alkaline water electrolysis, Int. J. Hydrogen Energy. 22 (1997) 493-500. https://doi.org/https://doi.org/10.1016/S0360-3199(96)00129-2.

[64] M.L. Chelaghmia, M. Nacef, A.M. Affoune, Ethanol electrooxidation on activated graphite supported platinum-nickel in alkaline medium, J. Appl. Electrochem. 42 (2012) 819-826.

[65] A.F.B. Barbosa, V.L. Oliveira, J. van Drunen, G. Tremiliosi-Filho, Ethanol electrooxidation reaction using a polycrystalline nickel electrode in alkaline media: Temperature influence and reaction mechanism, J. Electroanal. Chem. 746 (2015) 3138. https://doi.org/https://doi.org/10.1016/j.jelechem.2015.03.024.

[66] C. Xu, Y. Hu, J. Rong, S.P. Jiang, Y. Liu, Ni hollow spheres as catalysts for methanol 
and ethanol electrooxidation, Electrochem. Commun. 9 (2007) 2009-2012.

https://doi.org/https://doi.org/10.1016/j.elecom.2007.05.028.

[67] A.N. Golikand, M. Asgari, M.G. Maragheh, S. Shahrokhian, Methanol electrooxidation on a nickel electrode modified by nickel-dimethylglyoxime complex formed by electrochemical synthesis, J. Electroanal. Chem. 588 (2006) 155-160. https://doi.org/https://doi.org/10.1016/j.jelechem.2005.11.033.

[68] A. Cuña, C. Reyes Plascencia, E.L. da Silva, J. Marcuzzo, S. Khan, N. Tancredi, M.R. Baldan, C. de Fraga Malfatti, Electrochemical and spectroelectrochemical analyses of hydrothermal carbon supported nickel electrocatalyst for ethanol electro-oxidation in alkaline medium, Appl. Catal. B Environ. 202 (2017) 95-103. https://doi.org/https://doi.org/10.1016/j.apcatb.2016.08.063.

[69] B. Habibi, N. Delnavaz, Electrooxidation of glycerol on nickel and nickel alloy (Ni-Cu and Ni-Co) nanoparticles in alkaline media, RSC Adv. 6 (2016) 31797-31806.

[70] M. Fleischmann, K. Korinek, D. Pletcher, The oxidation of organic compounds at a nickel anode in alkaline solution, J. Electroanal. Chem. Interfacial Electrochem. 31 (1971) 39-49. https://doi.org/https://doi.org/10.1016/S0022-0728(71)80040-2.

[71] O. Movil, M. Garlock, J.A. Staser, Non-precious metal nanoparticle electrocatalysts for electrochemical modification of lignin for low-energy and cost-effective production of hydrogen, Int. J. Hydrogen Energy. 40 (2015) 4519-4530. https://doi.org/10.1016/j.ijhydene.2015.02.023. 

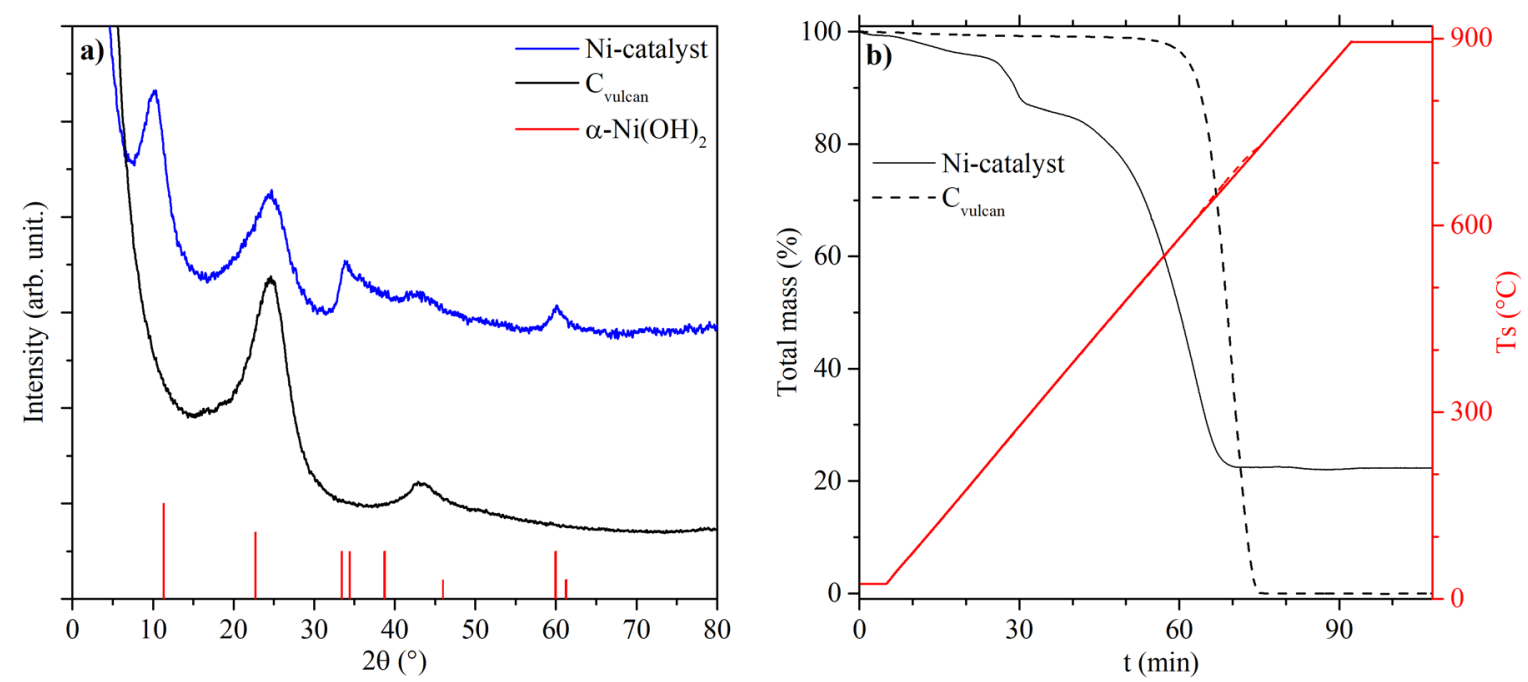

Figure 1. Characterization of the as-prepared $\mathrm{Ni} / \mathrm{C}$ catalyst and the Vulcan $\mathrm{XC}-72$ carbon support: a) XRD diffraction (together with $\alpha-\mathrm{Ni}(\mathrm{OH})_{2}$ patterns, JCPDS NO. 38-0715), b) TGA analysis under air flow $\left(30 \mathrm{~mL} \mathrm{~min}^{-1}\right)$. Heating conditions: from $25{ }^{\circ} \mathrm{C}$ to $900{ }^{\circ} \mathrm{C}$, with a heating rate of $10^{\circ} \mathrm{C} \mathrm{min}^{-1}$. 

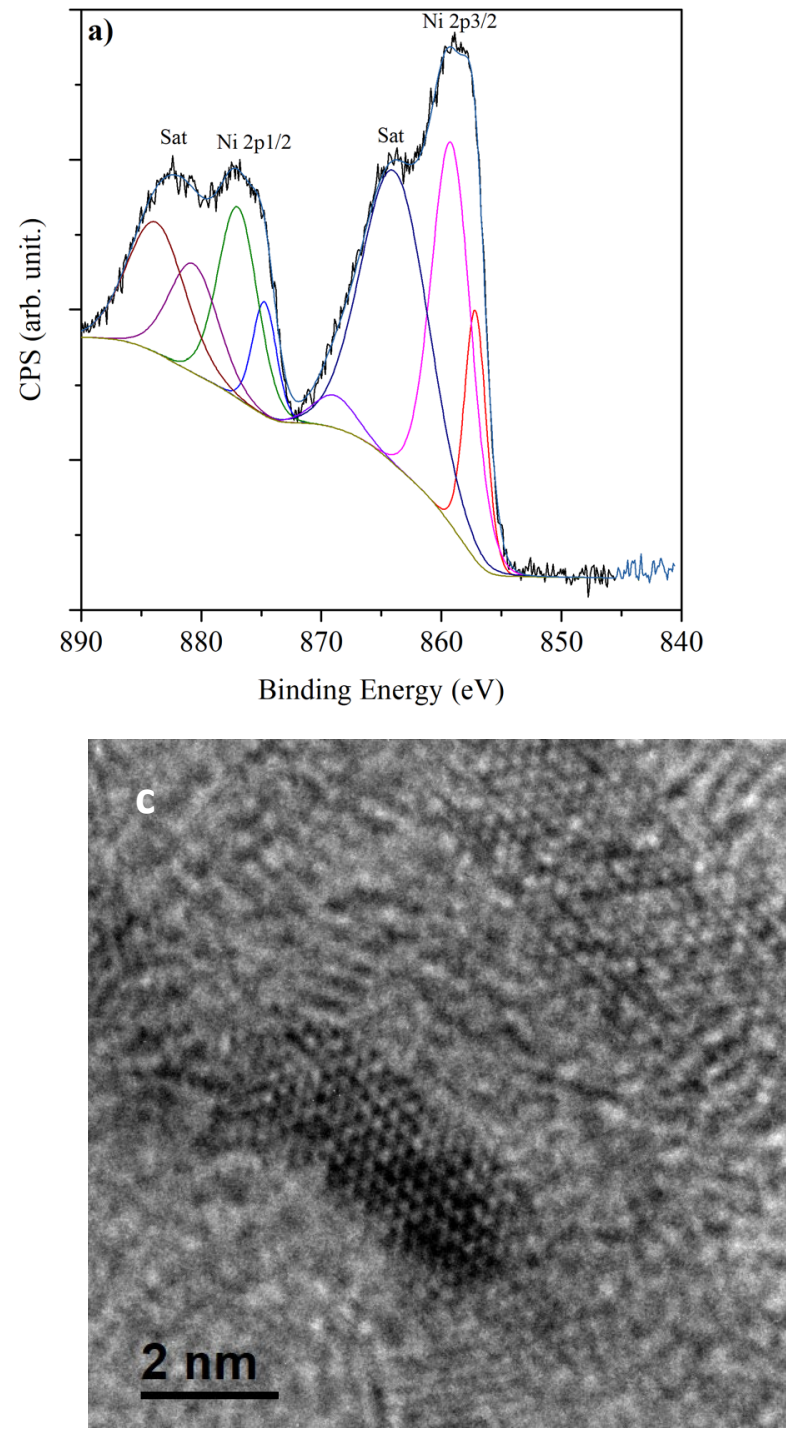
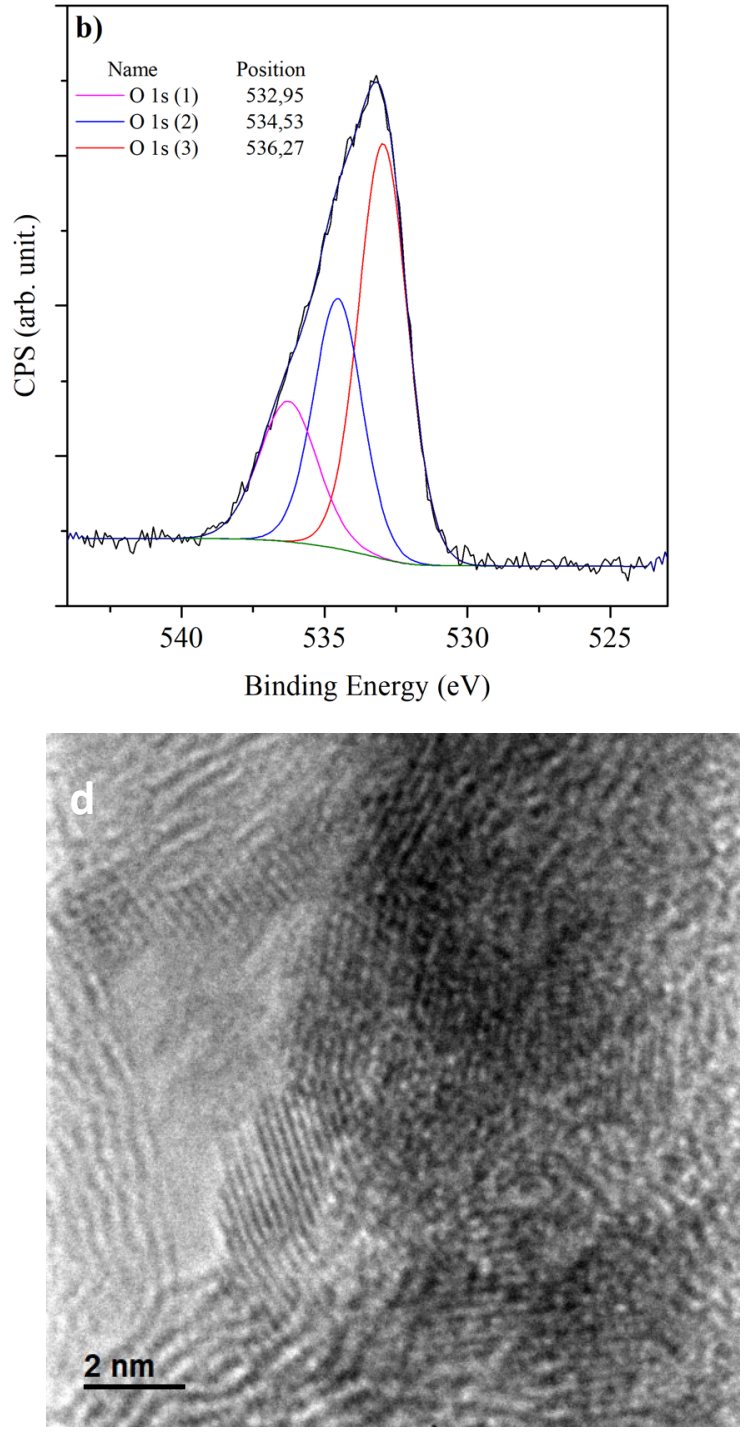

Figure 2. Characterization of the as-prepared $\mathrm{Ni} / \mathrm{C}$ catalyst by XPS and high-resolution TEM. XPS spectra in the region $\mathrm{Ni}_{2} \mathrm{p}_{1 / 2}$ and $\mathrm{Ni}_{2} \mathrm{p}_{3 / 2} \mathrm{a}$ ), and $\mathrm{O}_{1 \mathrm{~s}} \mathrm{~b}$ ). Representative TEM micrographs c-d). 

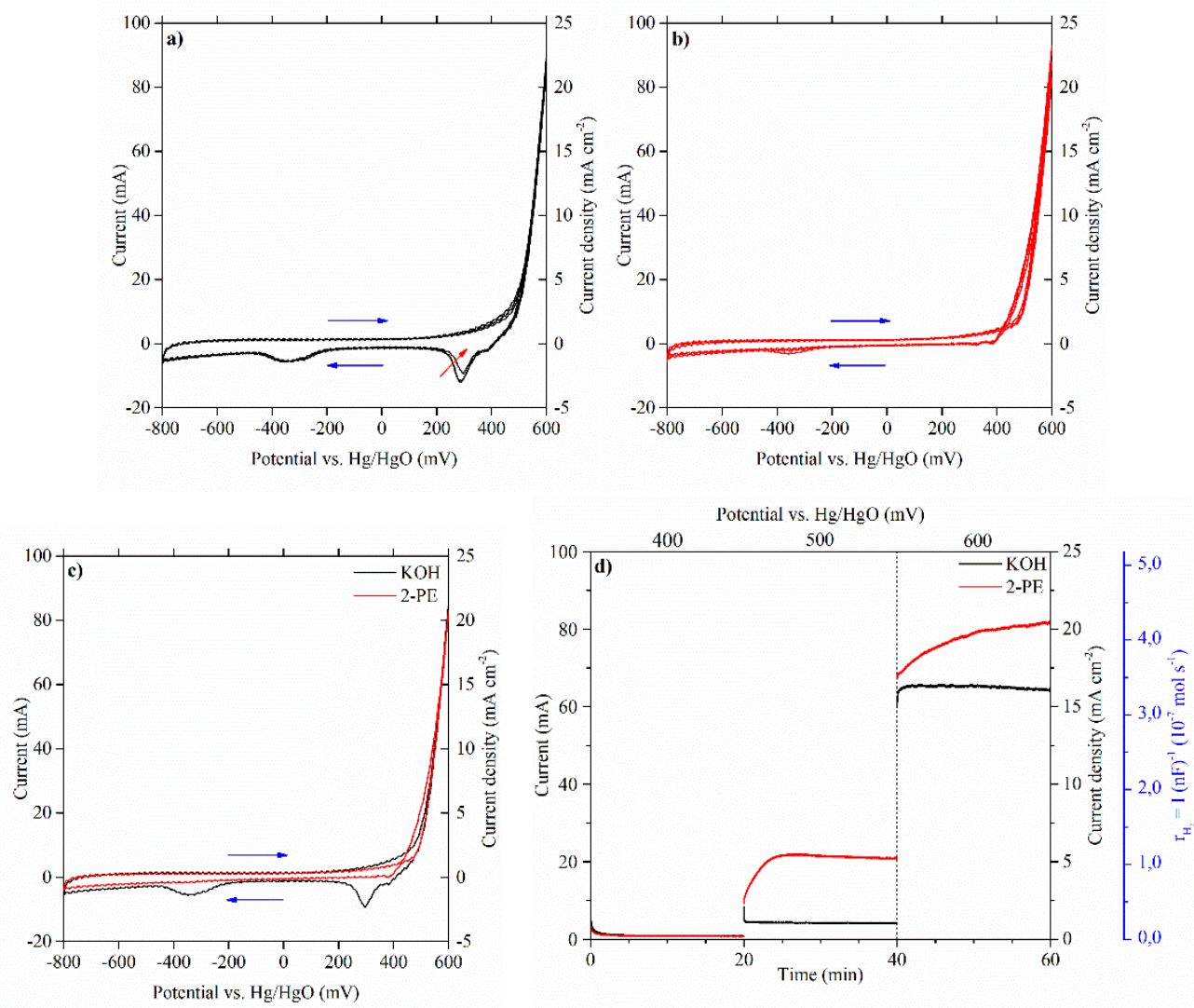

Figure 3. Electrochemical experiments in a 3-electrode cell: a) Cyclic voltammetry of a $\mathrm{KOH}$ $1 \mathrm{M}$ solution ( $\mathrm{scan}$ rate $10 \mathrm{mV} \mathrm{s}^{-1}$ ) from -800 to $600 \mathrm{mV}$ vs. $\mathrm{Hg} / \mathrm{HgO}$ (only $2^{\text {nd }}, 5^{\text {th }}$ and $10^{\text {th }}$ cycle), b) cyclic voltammetry of a 2-phenoxyethanol solution $\left(10 \mathrm{~g} \mathrm{~L}^{-1}\right.$ in $\mathrm{KOH} 1 \mathrm{M}$, scan rate $10 \mathrm{mV} \mathrm{s}^{-1}$ ) from -800 to $600 \mathrm{mV}$ vs. $\mathrm{Hg} / \mathrm{HgO}$ (only $2^{\text {nd }}, 5^{\text {th }}$ and $10^{\text {th }}$ cycle), c) comparison of the $10^{\text {th }}$ cycle of both $\mathrm{CV}$ experiences, d) chrono-amperometry from 400 to $600 \mathrm{mV}$ vs.

$\mathrm{Hg} / \mathrm{HgO}$ under a step change of $100 \mathrm{mV}$ (20 min at each potential). Solution volume: $150 \mathrm{~mL}$. Temperature: $60{ }^{\circ} \mathrm{C} . \mathrm{N}_{2}$ purge 15 min prior and during the experience. 


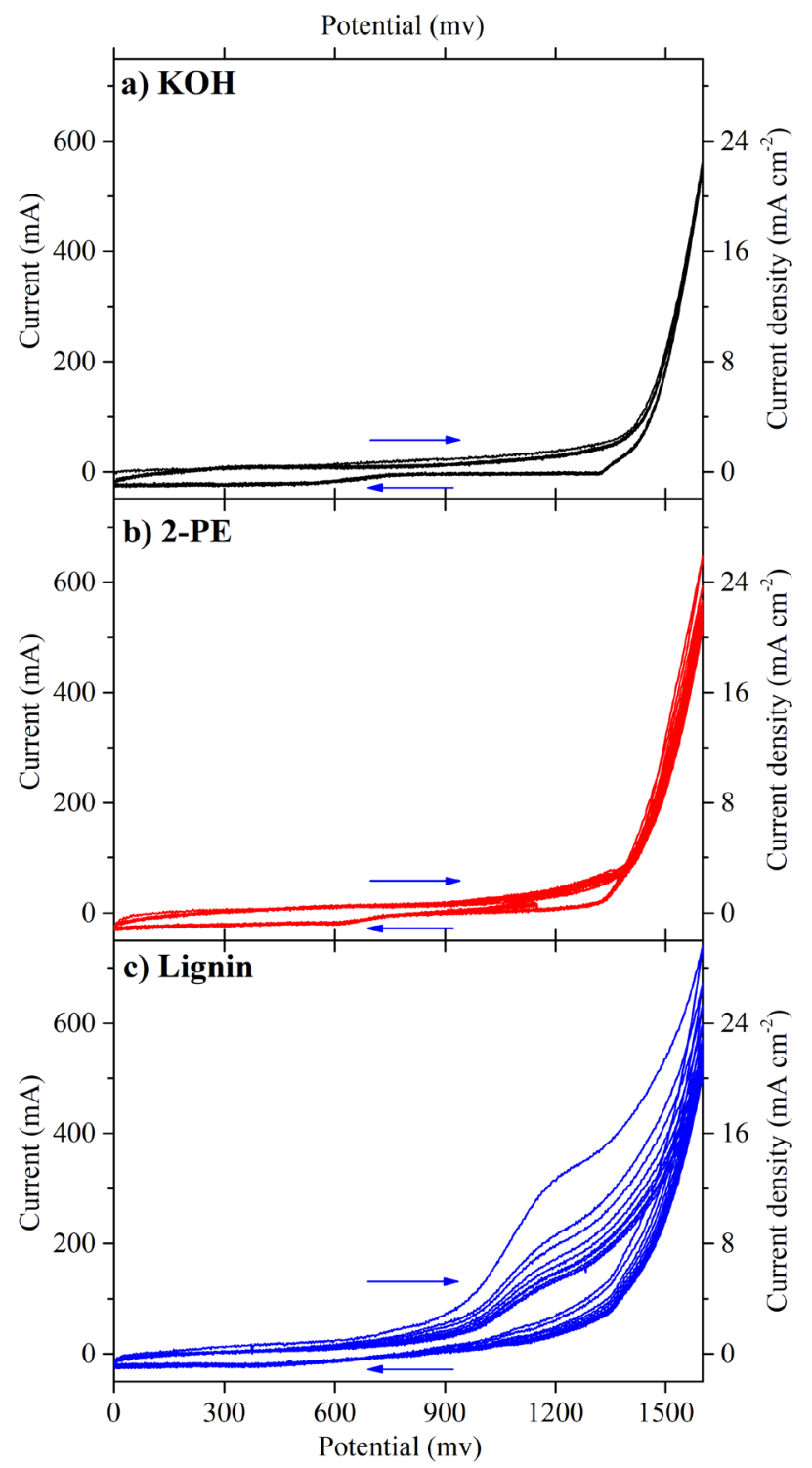

Figure 4. Cyclic voltammetry experiments in an AEM cell from 0 to $1600 \mathrm{mV}$ (10 cycles, scan rate $10 \mathrm{mV} \mathrm{s}^{-1}$ ) by varying the composition of the anodic solution to: a) $\mathrm{KOH} 1 \mathrm{M}$ solution, b) 2-phenoxyethanol solution $\left(10 \mathrm{~g} \mathrm{~L}^{-1}\right.$ in $\left.\mathrm{KOH} 1 \mathrm{M}\right)$, c) alkali (Kraft) lignin $\left(10 \mathrm{~g} \mathrm{~L}^{-1}\right.$ in $\mathrm{KOH} 1 \mathrm{M})$. Cathodic solution: $\mathrm{KOH} 1 \mathrm{M}$. Volume of the anodic reservoir: $30 \mathrm{~mL}$. Volume of the cathodic reservoir: $200 \mathrm{~mL}$. Liquid flow rate: $1.8 \mathrm{~mL} \mathrm{~min}{ }^{-1}$. Temperature: $80{ }^{\circ} \mathrm{C}$. 

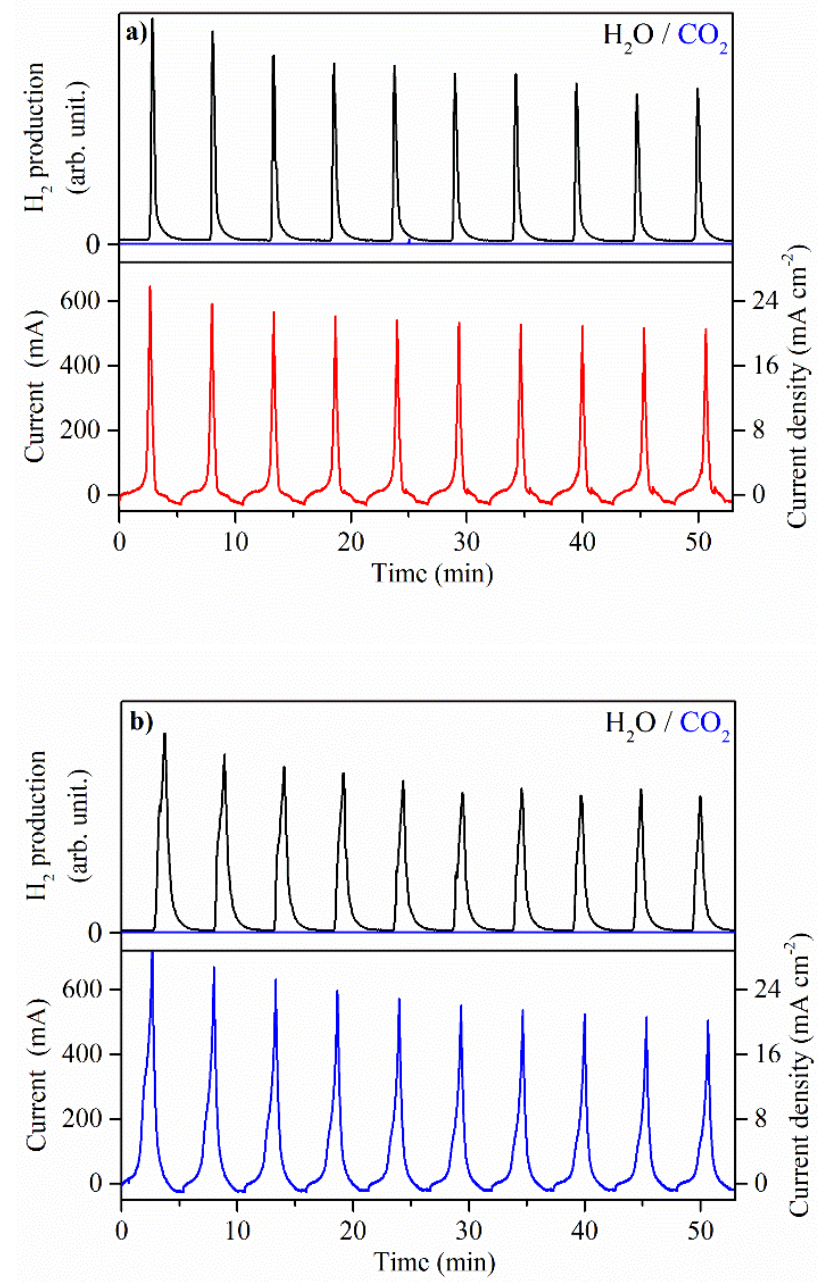

Figure 5. In-situ $\mathrm{H}_{2}(\mathrm{~m} / \mathrm{z}=2 \mathrm{amu})$ and $\mathrm{CO}_{2}(\mathrm{~m} / \mathrm{z}=44 \mathrm{amu})$ measuring by mass spectrometry (He dilution flow of $33 \mathrm{~mL}$ min-1) during the cyclic voltammetry experiment described in Fig. 4 for: a) 2-phenoxyethanol anodic solution $\left(10 \mathrm{~g} \mathrm{~L}^{-1}\right.$ in $\left.\mathrm{KOH} 1 \mathrm{M}\right)$, and b) alkali (Kraft) lignin $\left(10 \mathrm{~g} \mathrm{~L}^{-1}\right.$ in $\left.\mathrm{KOH} 1 \mathrm{M}\right)$. 


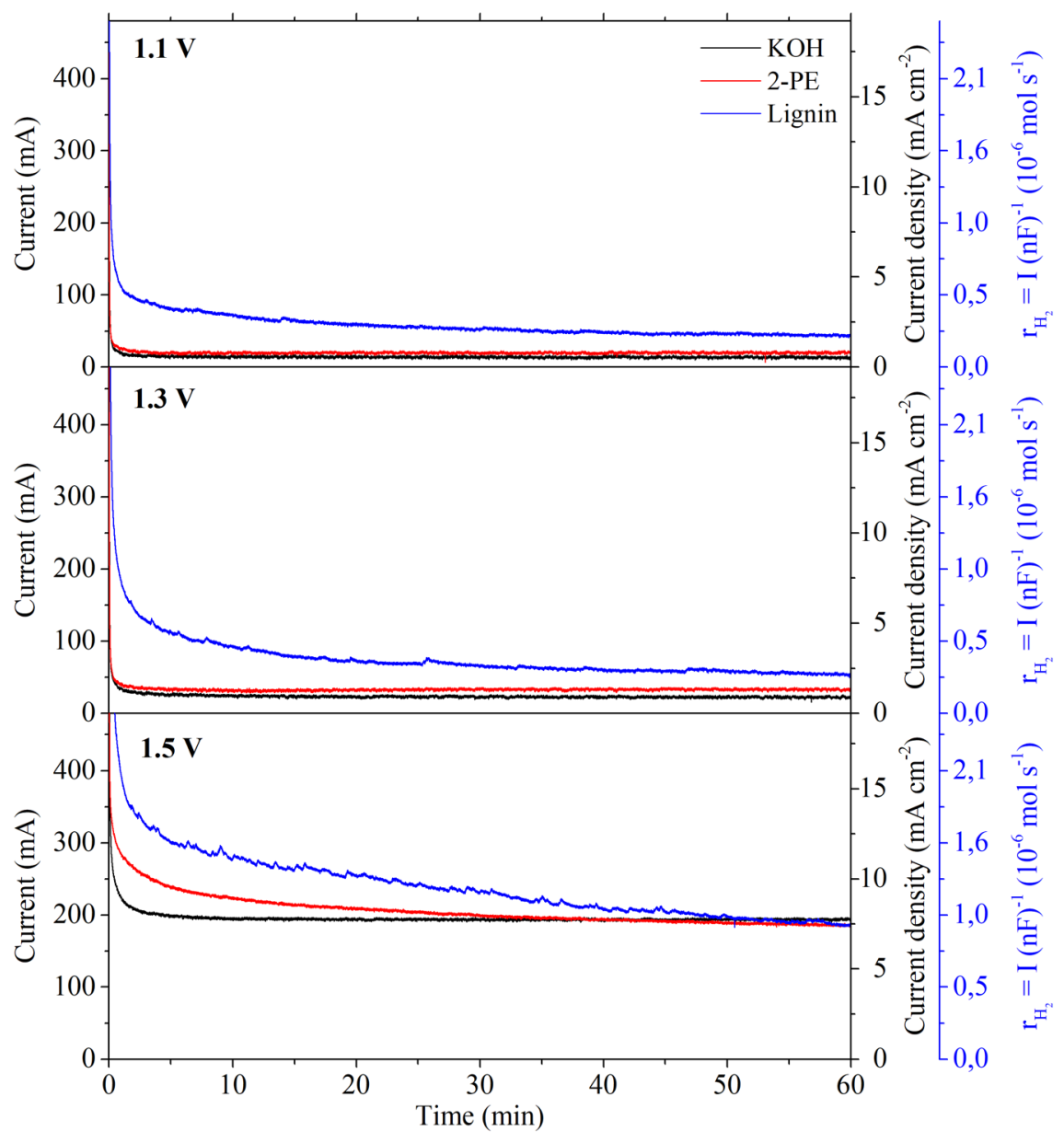

Figure 6. Chrono-amperometry experiments under different applied potentials in the AEM cell: a) $1.1 \mathrm{~V}$, b) $1.3 \mathrm{~V}$, c) $1.5 \mathrm{~V}$. Anode solutions: $\mathrm{KOH} \mathrm{1M}$, 2-phenoxyethanol solution (10 g $\mathrm{L}^{-1}$ in $\left.\mathrm{KOH} 1 \mathrm{M}\right)$, alkali (Kraft) lignin $\left(10 \mathrm{~g} \mathrm{~L}^{-1}\right.$ in $\left.\mathrm{KOH} 1 \mathrm{M}\right)$. Cathode solution: $\mathrm{KOH} 1 \mathrm{M}$.

Solution volumes: $30 \mathrm{~mL}$. Liquid flow rate: $1.8 \mathrm{~mL}$ min-1. Temperature: $80{ }^{\circ} \mathrm{C}$. 